Policy Research Working Paper 5019

\title{
Determinants of Globalization and Growth Prospects for Sub-Saharan African Countries
}

Hippolyte Fofack

The World Bank

World Bank Institute

Poverty Reduction and Economic Management Division 
Policy Research Working Paper 5019

\begin{abstract}
Over the decades leading to the global financial crisis, the world witnessed a deepening integration of world economies, irrespective of a country's geographical location on the spherical space. This process of increasing interdependence of world economies, most notably illustrated by the scale of financial flows and movements of goods and services now termed globalization, has been facilitated by research and development and advances in technology, especially in the area of information and communication technology. In spite of its global nature, its expected benefits have not been uniformly distributed, however. This paper shows that the countries and regions
\end{abstract}

that are driving the process of knowledge creation and production of high-tech and manufactured goods, building on frontier technology, are benefiting the most from globalization, increasingly acting as drivers and relegating Sub-Saharan Africa to the end-user status. In this process, the income gap between Sub-Saharan Africa and the globalizers has increased even more. However, the paper also shows that raising the level of technological endowment in Sub-Saharan Africa to that of developed countries could go a long way to bridge Africa's output gaps and improve its export performance in the new globalization landscape of the post-financial crisis era.

This paper-a product of the Poverty Reduction and Economic Management Division, World Bank Institute—is part of a larger effort in the department to understand the determinants of globalization and their implications for growth and economic development in a context of deepening integration of world economies. Policy Research Working Papers are also posted on the Web at http://econ.worldbank.org. The author may be contacted at hfofack@worldbank.org.

The Policy Research Working Paper Series disseminates the findings of work in progress to encourage the exchange of ideas about development issues. An objective of the series is to get the findings out quickly, even if the presentations are less than fully polished. The papers carry the names of the authors and should be cited accordingly. The findings, interpretations, and conclusions expressed in this paper are entirely those of the authors. They do not necessarily represent the views of the International Bank for Reconstruction and Development/World Bank and its affliated organizations, or those of the Executive Directors of the World Bank or the governments they represent. 


\title{
Determinants of Globalization and Growth Prospects for Sub-Saharan African Countries
}

\author{
Hippolyte Fofack ${ }^{1}$ \\ The World Bank Group, Washington DC
}

JEL Classifications: E66, C33, F14, N10, O33.

Keywords: Economic diversification, globalization, globalizers and globalizees.

\footnotetext{
1 This paper has benefited greatly from suggestions and comments by Pierre-Richard Agénor, Shanta Devarajan, Ibrahim Elbadawi, Leonce Ndikumana, Roumeen Islam, Raj Nallari, Yaw Nyarko and Etienne Yehoue; I would like to thank them all for their contribution which helped improved earlier drafts. In addition, I would like to thank seminar participants at the African Development Bank Economic Conference held in Tunis in November 2008 and particularly Ron Leung, the discussant, for their constructive comments and suggestions. I would also like to thank Nihal Bayraktar for excellent research assistance.
} 


\section{Introduction}

With the deepening integration of national economies, the world witnessed sustained output expansion and increase exports of manufactured goods over most of the decades leading to the 2008 global financial crisis [IMF (2007)]. However, in a major trend reversal, the global financial shock prompted by the US subprime mortgage explosion late last year pushed many countries into the tailspin of depression. This crisis was particularly severe as reflected in the scale of output decline at the global level. On an annual basis in 2009, output is projected to decline in advanced economies, marking the first contraction in the post-war period for this group of countries [IMF (2009)]. In addition, the crisis led to unprecedented collapses in asset prices as well as in equity and bond markets, dramatic drop in global trade and capital flows [Reinhart and Rogoff (2009)].

In spite of the massive injection of fiscal stimulus resources in the economy as part of aggressive countercyclical policy measures implemented in a large number of industrialized countries, the ramifications of this crisis are still hard felt. Rising unemployment rates and growing fiscal deficits, particularly in advanced economies, are part of the growing stream of negative spillover effects associated with the ongoing crisis. The speed of transmission across countries is another major characteristic of it, probably reflecting the relatively matured nature of economic and financial globalization, but also the inherent risk associated with such a process. ${ }^{2}$

Prior to the crisis, global exports had been growing unabated since the 1970s, and reached the critical threshold of US $\$ 17$ trillion in 2007, representing a tenfold increase over the last three decades. Interestingly, this remarkable surge has also been accompanied by a parallel increase in capital flows. Estimates suggest that global capital flows exceeded a trillion US dollar in the precrisis era [World Bank (2007)]. And a significant proportion of resources is primarily deployed either to finance foreign direct investments or for portfolios diversification motives, particularly in a context of globalization of corporate finance and emergence of attractive equity and capital markets in a growing number of developing countries [Word Bank (2006), (2007)]. ${ }^{3}$

Of course, the process of integration of world economies is not new. Historical data suggest that there have been at least three waves of unprecedented booms in global trade since 1870 [Maddison (2001), World Bank (2002a)] ${ }^{4}$. However, the scale and speed in movements of goods and services in earlier waves of export booms were of smaller magnitude. Furthermore, the process was highly concentrated, largely driven by a small number of countries, first by industrialized countries in Europe, and then later followed by latecomer nations, especially in the new world [Gerschenkron (1962), Maddison (1995, 2001)]. ${ }^{5}$

\footnotetext{
${ }^{2}$ Although this recession was trigerred by the US subprime financial crisis, it was almost instantaneously transmitted to other major financial centers and countries, especially in Europe and Asia.

3 To the extent that corporate finance primarily focuses on raising capital for corporations under a model that maximizes corporate values while reducing firm's financial risks, the financial globalization which increases the pool of investors and hence competition at the global level should lower the costs of funds and increase profits margins for multinational corporations.

${ }^{4}$ According to Maddison (2001), three major waves of accelerated trade have been observed in the world since 1870: the first wave started in 1870 and lasted through World War I in 1914; the second wave kicked off in 1950 and went all the way to 1980; the third wave has spanned the last three decades.

${ }^{5}$ Key among these latecomer nations are the USA and Germany, which in the previous centuries relied on technological catch-up strategies to bridge their knowledge and development gaps [Gerschenkron (1962)].
} 
Unlike initial waves the current episode of deepening integration of world economies involves a larger number of countries sampled throughout the globe. Additionally, economic and financial flows have not been unidirectional under this last episode. In fact, developing countries enjoying large and sustained current account surpluses have become net exporters of capital to advanced economies, in defiance of economic theory [Lucas (1988), Summers (2006)]. In this regard, the latest episode of deepening integration of national economies has been more inclusive and global, with the process fostering interdependence of countries and world markets. However, the inherent adverse effect is the increase risk of contagion as illustrated by the magnitude of the ongoing financial crisis.

In part, this remarkable surge in global trade reflects sustained output growth and exports of manufactured goods in a context of rising global demands. In turn, the positive response to global demands is facilitated by advances in technology, particularly in the area of information and communication technology, and productivity enhancement. This surge in global trade also reflects the convergence of consumption patterns, and the emphasis on standards and norms in the production of goods, and less on the source and country of origin. Hence, in light of its highly integrative nature this last wave of exceptional surge in international trade has been termed globalization.

Globalization can be defined as a significant reduction of time-scale in the movement of goods, capital and knowledge in a spherical space, in spite of the constant distance between source country and final destination, as a result of technological advances and increasing interdependence and connectivity of world markets. ${ }^{6}$ Under the compression of both temporal and spatial dimension the world has been trending toward one global market with more efficient pricing mechanisms, and an increasingly large share of economic activities are carried out across national borders [Friedman (2005), Leamer (2007)]. ${ }^{7}$

The more inclusive nature of this last episode of deepening integration of world economies also reflects a successful economic diversification achieved by a growing number of developing countries, most notably in Asia and Latin America. The diversification of sources of growth in these regions of the developing world has resulted in impressive rates of economic growth in a large number of countries now commonly known as emerging market economies [Goldstein et al. (2006), Agosin (2005)]. Consistent with neo-classical growth models, sustained growth rates in these economies has resulted in a reduction of welfare gaps and income convergence with traditional industrialized nations [Ben-David (1998), Mathews and Hu (2007)].

However, in spite of its more integrative nature, Sub-Saharan Africa did not benefit as much from the ensuing economic gains which arose from the current wave of globalization prior to the crisis. In fact, most countries in Sub-Saharan Africa saw their per capita income decline in real terms, just as income convergence between industrial and emerging market economies was becoming apparent [Easterly and Levine (1997), Artadi and Sala-i-Martin (2003)]. ${ }^{8}$ These divergent growth paths and outcomes in the developing world, characteristics of the last wave of

${ }^{6}$ Globalization has also been defined in terms of a set of policies and programs designed to enhance free trade. Under this definition, the process of globalization is led by a number of institutions and countries, which are considered globalizers, in reference to the fact that they are advocating policies that will foster the process of globalization [Woods (2006)].

${ }^{7}$ In particular, this trend towards the global economy has produced a new configuration where the contribution of emerging market economies to global trade has grown significantly.

${ }^{8}$ In fact most countries in the region recorded negative growth rates over the period; the few exceptions include Botswana, Mauritius and Cape Verde which grew to the middle-income country status [Ndulu (2006)]. 
globalization, have created two worlds in the developing world: the developing world of emerging market economies and the rest, with the latter overwhelmingly dominated by SubSaharan African economies.

The structural patterns of most economies in Sub-Saharan Africa have remained static, and most countries continue to operate far below the global technology frontiers. Conceivably, the divergent economic outcomes between Sub-Saharan African countries and emerging market economies in Asia are partly a reflection of different patterns of growth. While the latter adopted development models emphasizing capital accumulation and structural transformation, particularly including industrial expansion required for manufactured output growth, the former opted for static models inherited from the colonial era [Amsden (2003)]. Under these models, the connection of Sub-Saharan African countries to the global economy is mainly through primary commodities and raw material exports [Goldstein et al. (2006)].

Yet advances in technology and innovations, which played a key role in the process of industrial development and globalization during the first waves of economic integration, were equally critical in the latest wave [Maddison (2001), Fofack (2008)]. The income convergence between emerging market economies and the traditional industrialized nations is therefore partly attributed to an increasing reduction of technological gaps in the former. However, the process of technology acquisition and efficient utilization and applications of that technology for economic diversification and integration into the global economy also require good institutional frameworks for human and physical capital accumulation.

This paper outlines an analytical framework to assess the impact of globalization for economic development in Sub-Saharan Africa. The paper aims to achieve two main objectives. First, it provides a comprehensive review of the determinants of globalization in the pre-crisis era using a sequential pseudo-panel model. While some aspects of globalization, particularly as it relates to growth and poverty [Agénor (2002), Stiglitz (2003, 2006)] ${ }^{9}$, have been assessed, an in-depth econometric analysis of its determinants has yet to be undertaken. Secondly, the paper highlights a number of critical challenges that countries in Sub-Saharan Africa should overcome to enhance their integration into the global economy, and achieve global income convergence, while at the same time mitigating the costs of increased interdependence and transmission of international risks in a flat world where movements of goods and services are rapidly becoming space and time invariant.

Empirical results suggest that globalization has several drivers, including technological endowment and efficiency factors. Among the technology variables, the stock of resident researchers, high-tech and manufacturing goods components of aggregate output are significant determinants of globalization, which have enhanced long-run growth in the successful globalizers' nations. However, policy experiments suggest that raising Sub-Saharan African countries stock of researchers to OECD levels would result in significant improvement of the region's growth and export performance. The preeminence of knowledge further supports the role that manufactured output expansion has played in the process of globalization over the years. This has significant policy implications for the majority of Sub-Saharan African countries, which must address the challenges of persistent technological gaps and move towards a global production possibility frontier to fully take advantage of globalization.

${ }^{9}$ In particular, in order to enhance the global benefits of globalization, Stiglitz calls for the establishment of a new global social contract underpinned by the commitment of developed countries to a fairer trade regime, which actually promotes development. For further details, see Stiglitz (2006). 
The remainder of the paper is divided as follows. The next section provides an overview of the globalization process, contrasting economic and financial flows and highlighting variations in the distinctive regional contributions to the globalization process. Section 3 provides a conceptual framework for assessing the determinants of globalization. Section 4 focuses on empirical analysis and policy implications for countries in Sub-Saharan Africa. Section 5 provides concluding remarks.

\section{The New Globalization Landscape}

Although the process of globalization has spanned several centuries, the latest episode, which ran up to the 2008 global downturn, has been broader and deeper. The end result has been the emergence of a completely new globalization landscape in which emerging markets economies are playing an increasingly greater role [IMF (2007), Summers (2006)]. The increasing depth under this new landscape is most notably illustrated by the extent and speed of capital flows and international trade. The rates of growth in global trade have been impressive, with underlying distributions almost following an exponential growth path over the decades preceding the global financial crisis. The impressive depth is further illustrated by a parallel surge in capital flows, in scale only comparable to the magnitude of trade flows.

While the Gold Standard system in effect during earlier waves of deepening integration of world economies might have been a constraint to a concurrent rise in global trade and capital flows, the covariation of trade and capital flows represents a significant departure from earlier episodes of globalization. Presumably, this departure is facilitated by the new world economic order, which opened the doors to the glorious age of the pure dollar standard when the flexible exchange rate became solely anchored on pure paper money in the early 1970s [Mundell (1997)]. ${ }^{10}$ This new international monetary arrangement propelled the US dollar into its current dominance as international currency, enabling it to emerge as a perfect substitute to the gold-anchored fixed exchange rate regime adopted at the Bretton Woods conference.

Figure 1 provides the long-term trend of global capital flows (solid and thin line) and exports of goods and services (solid and thick line) since the 1970s, when the age of pure paper money was effectively launched. However, the period is sufficiently long and covers the latest wave of globalization, which effectively started with full-blown deregulation in the 1980s [Stiglitz (2006)]. Since then, global trade has grown unabated, notwithstanding occurrences of spasms of economic downturns. While the volume of international trade grew by more than tenfoldincreasing from less than US $\$ 1.5$ trillions in 1970 to over US $\$ 17$ trillions in 2007 - the rate of growth of capital flows was equally impressive, especially in the aftermath of the East Asian financial crisis.

The continued rise in capital flows up to the tail end of the distribution, in spite of the Asian financial crisis, which temporarily resulted in a sudden stop in global capital flows in the late 1990s further supports the co-variation and dependency structure in the distributions of global

\footnotetext{
10 The breakdown of the Gold Standard did not come without costs, however. An international monetary system linked to gold helped manage interdependence of the currency system, established an anchor for fixed exchange rates and stabilized inflation. The transition to pure dollar standard undermined the performance of these functions, with the world moving into regime of permanent inflation [Mundell (1997)].
} 
trade and capital flows [Coulibaly and Millar (2008)]. ${ }^{11}$ The co-variation and time-dependency structure of these two distributions are certainly important stylized facts of the new globalization landscape. In fact, with a growing share of economic activities carried out across national borders, capital flows may be driven by foreign direct investments in support of industrial output expansion in a context of rising global demands. ${ }^{12}$

Figure 1: Global trade and net capital flows (in billions of current US\$)

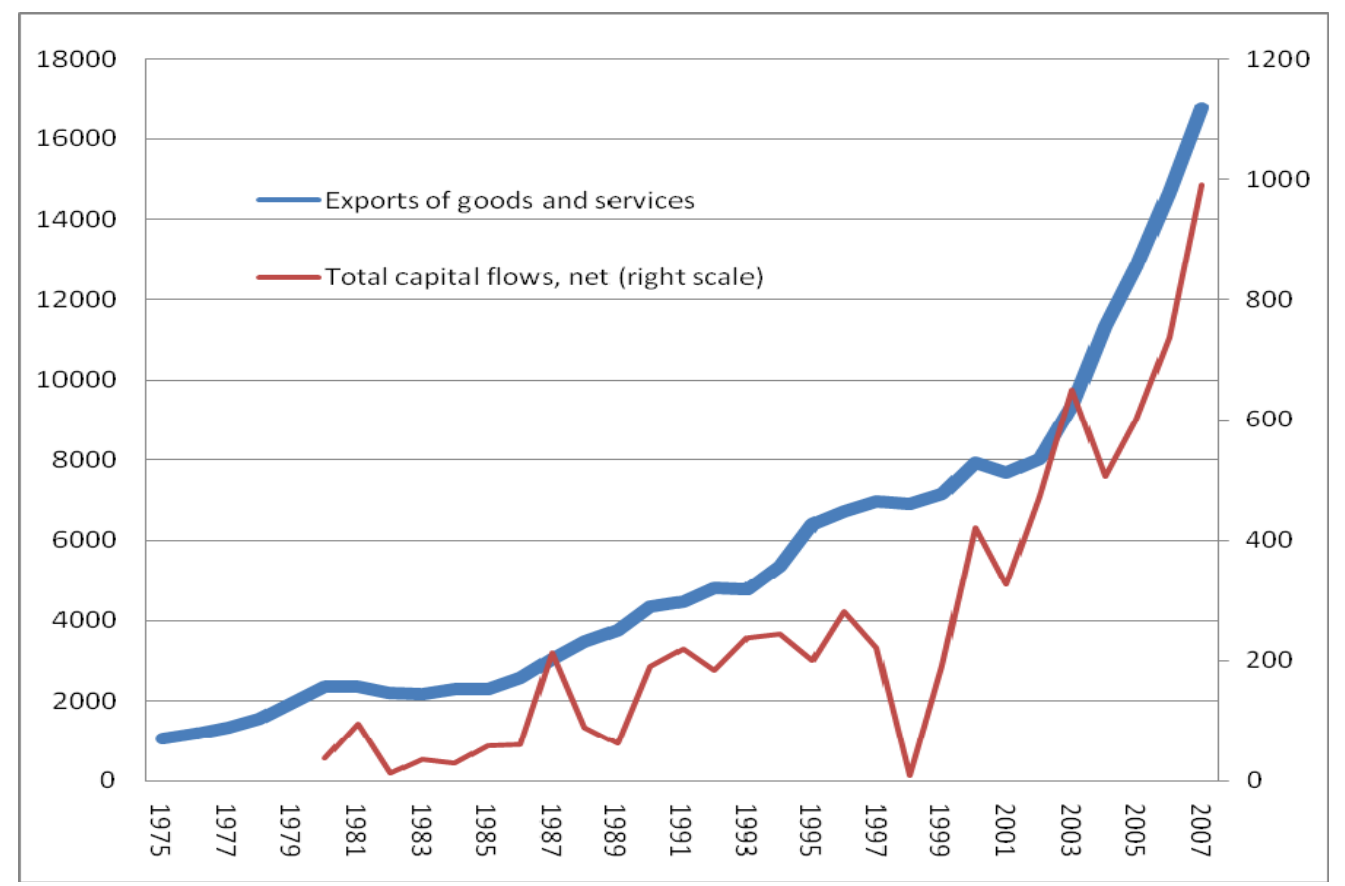

Source: World Bank World Development Indicators.

Two different measures of association applied to the data support the positive correlation between global capital flows and trade. The rank correlation coefficient from a nonparametric test of independence is relatively high $(\rho=0.86)$, suggesting that increasing international trade is associated with rising capital flows. This positive association is also supported by the Pearson product moment correlation coefficient $(\theta=0.93)$. A measure of correlation of this magnitude suggests that a strong positive linear relationship exists between these variables.

The global trend in international trade and capital flows need not mask persistent variations across countries and regions, however. The persistency of regional variations is yet another important characteristic of the new globalization landscape. Just like in the previous waves of deepening integration of global economies, the contribution of different regions to global trade

${ }^{11}$ The Asian financial crisis which affected most emerging markets economies in 1997 resulted in a sharp drop in investments. It is believed that the crisis was caused by a sudden shortage of foreign exchange following capital flows reversal in economies which have become heavily dependent on private operators borrowing abroad to fund capital investments.

${ }^{12}$ To the extent that correlation does not necessarily imply causation, it may be important to assess the nature of the association, and particularly the extent to which the impressive scale of capital flows may be driven by output expansion and global trade using Granger causality tests. 
has been neither uniform nor stable under the new globalization landscape [World Bank (2007)]. Although much more integrated, the new landscape remains skewed, partly as a result of a significant decline in the contribution of Sub-Saharan African countries to global output growth and exports over the last decades of sustained economic growth and boom in international trade.

In contrast, the remarkable gains achieved by emerging markets economies, particularly in Asia where capital accumulation was strong and economic growth rates were sustained, markedly increased the contribution of these economies to global trade [Yusuf and Nabashima (2007), IMF (2007)]. And in a zero sum game framework, the anemic growth and high volatility recorded in most countries in Sub-Saharan Africa, where investment rates fell dramatically, resulted in a significant decline of Sub-Saharan Africa's contribution to global trade [Akyuz and Gore (2001)]. This declining contribution reached an all-time low level of 0.6 percent in 2007, and is in sharp contrast to the dramatic increase of East Asia's overall share (see Table 1). ${ }^{13}$

Although significant, the declining share of Sub-Saharan Africa is not an exception; a similar downward trend is also apparent in a number of other regions, albeit on a less pronounced basis. The regional contribution to global trade for a number of regional trading blocs over the last three decades also highlights the changing globalization landscape. In particular, the sustained output growth and total factor productivity gains achieved by emerging market economies dramatically altered the global distribution of trade, with the contribution of the East Asia region rising to over 20 percent.

Table 1: Regional shares in global trade (in percentage of global trade)

\begin{tabular}{lllllllll}
\hline & 1975 & 1980 & 1985 & 1990 & 1995 & 2000 & 2005 & 2007 \\
\hline Euro Area & 31.3 & 31.3 & 30.2 & 35.5 & 32.7 & 28.5 & 29.3 & 29.3 \\
North America & 15.9 & 14.6 & 16.8 & 15.8 & 15.9 & 17.7 & 13.4 & 12.7 \\
$\quad$ USA & 12.3 & 11.4 & 12.5 & 12.4 & 12.4 & 13.5 & 10.1 & 9.7 \\
East Asia (incl. China) & 1.97 & 4.0 & 7.46 & 8.67 & 12.75 & 14.7 & 16.9 & 20.1 \\
Sub-Saharan Africa (SSA) & $\mathbf{1 . 5}$ & $\mathbf{3 . 4}$ & $\mathbf{2 . 4}$ & $\mathbf{1 . 8}$ & $\mathbf{1 . 3 2}$ & $\mathbf{1 . 3 4}$ & $\mathbf{1 . 5 9}$ & $\mathbf{0 . 6 4}$ \\
SSA (excl. South Africa) & 0.53 & 2.22 & 1.64 & 1.17 & 0.78 & 0.87 & 1.07 & 0.10 \\
\hline
\end{tabular}

Source: World Bank World Development Indicators.

Even the growing demands of primary commodities and raw materials from Sub-Saharan Africa in support of industrial output expansion in advanced and emerging market economies (in response to rising global demands) did not prevent the continued erosion and declining contribution of African countries to global trade. Worst of all, Sub-Saharan Africa's declining share of global trade is mirrored by a concomitant drop in its contribution to overall economic growth in Figure 2. Although already abysmally low-less than 4 percent in 1985, this contribution declined even further.

\footnotetext{
13 And when South Africa is excluded, the Sub-Saharan Africa's contribution to global trade is even lower, approximately $0.1 \%$ in 2007 .
} 
In contrast, the contribution of China which embraced the path of value addition and industrial output expansion averaged 20 percent over the reference period, suggesting an even larger share for the East Asia region, as a whole [Goldstein et al. (2006)]. Over the last few years, this exceptional contribution has continued to grow unabated. According to latest statistics, China now makes the largest country-level contribution to global growth, both in terms of purchasing power parity and at market prices [IMF (2007)].

Figure 2: Contribution to global growth between 1981 and 2007 (as a percentage of annual growth rate)

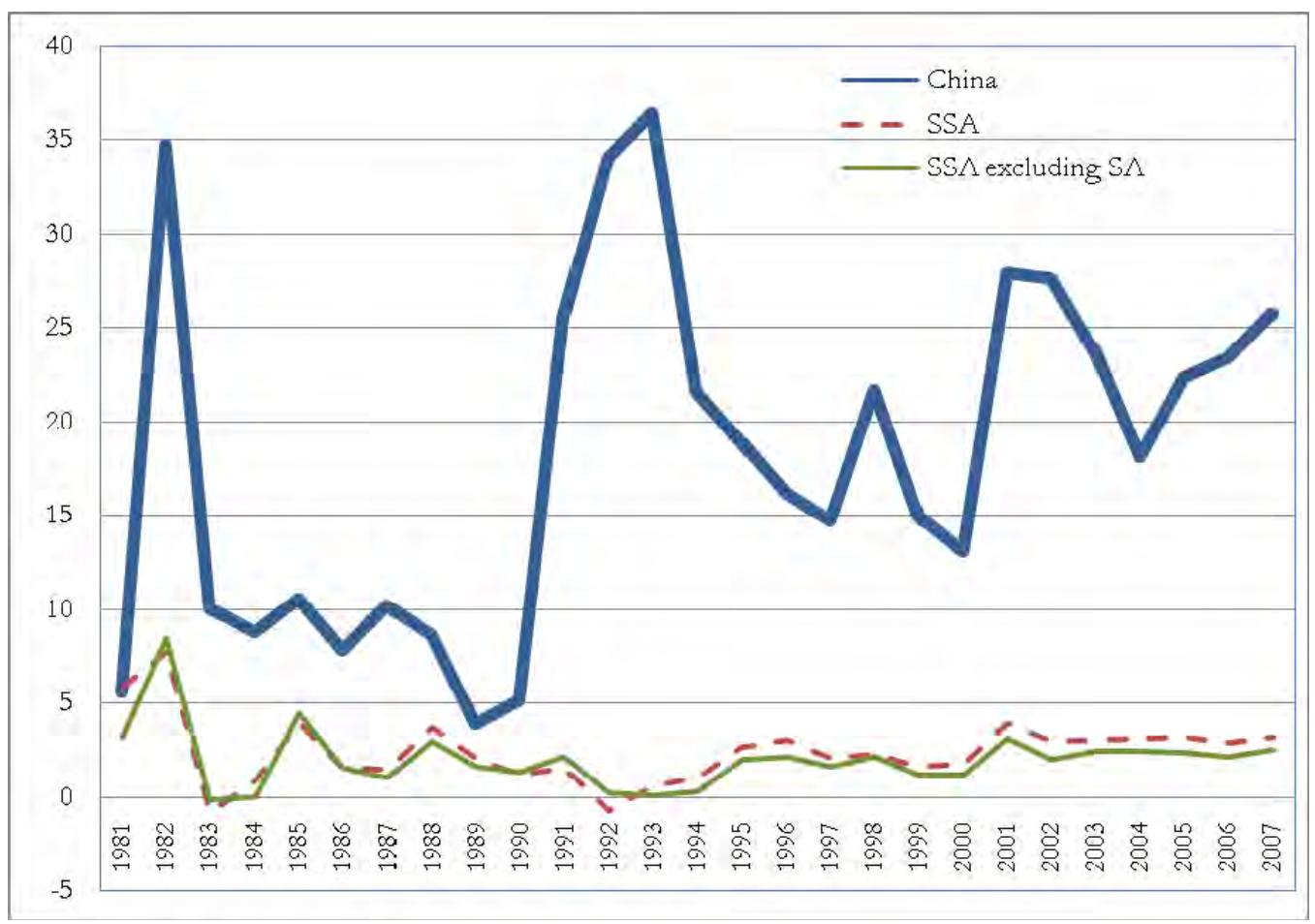

Source: World Bank World Development Indicators.

The declining position of Sub-Saharan Africa in the new globalization landscape notwithstanding, increasing demands for primary commodities is yet another important stylized fact of the new globalization landscape. It highlights how important the quality of growth increasingly matters for economic development in the new economy that is increasingly driven by knowledge and productivity growth [Okubo et al. (2006)]. ${ }^{14}$ Indeed, over the years, the process of globalization has largely been driven by expansion of industrial output and production of manufactured goods following advances in technology.

For unlike natural resources and extractive industries which tend to be more capital-intensive, industrial output expansion, and particularly the production of manufactured goods is more labor-intensive and hence can enhance broad-based economic growth and sustained increases in

\footnotetext{
${ }^{14}$ A study published by the US Department of Commerce in 2006 found that the contribution of knowledge is explaining an increasingly large part of the US multifactor productivity. For instance, it is estimated that multifactor productivity increased from approximately 20 percent to more than 33 percent between 1995 and 2002; and accounting for R\&D would explain over one-fifth of this factor in the late 1990 s.
} 
household income. Naturally, the welfare and growth potential of industrial output expansion are likely to be even more significant in countries where underlying development models value learning-by-doing [Jovanovic and Nyarko (1996)].

In this regard, structural economic transformation, although not sufficient, may be a necessary condition for a better integration into the new global economy. This transformation is all the more important for long-run growth, not least because primary commodity prices tend to decline vis-à-vis those of manufactured goods, a trend which has resulted in a continuous deterioration of net barter terms of trade and has fueled recurrent balance of payments crisis in a large number of primary commodity exporting countries in Sub-Saharan Africa [Goldstein et al. (2006)].15

Still, in the absence of structural transformation to achieve greater economic diversification, most countries in Sub-Saharan Africa continue to depend overwhelmingly on raw materials and primary commodity exports for foreign reserves [Fofack (2008)]. However, income elasticities of primary commodities tend to be lower than unity; at the same time, advances in technology which underpinned structural transformation in industrial and emerging market economies are resulting in demands for fewer raw materials per unit of manufactured goods.

The combination of these supply and demand side factors is partly responsible for the widening gap between the rising price of manufactured goods and primary commodities. Not surprisingly, overtime, the deterioration of barter terms of trade under the secular development models prevailing in most countries in Sub-Saharan Africa has resulted in recurrent balance of payments crisis and structural trade deficits [Easterly and Levine (1997), Artadi and Sala-i-Martin (2003)]. In response to recurrent balance of payments disequilibria countries resorted to foreign-deficit financing which resulted in debt overhang in the mid-1990s when the scope of external liabilities owed by the region to the rest of the world became unsustainable [Elbadawi et al. (1997)]. ${ }^{16}$

Contrasting this secular development model, recent trends and production patterns in emerging market economies have been characterized by increasing specialization and expanding scope of manufactured goods and exports diversification. At the macroeconomic level, this transformation has resulted in impressive reserves accumulation [Summers (2006), IMF (2007)]. ${ }^{17}$ The sustained buildup of foreign reserves following accumulation of current account surpluses in emerging market economies is certainly another important dimension of the new globalization landscape. ${ }^{18}$ Not the least, because these surpluses have enabled a number of emerging market economies to become net exporter of capital; in defiance of economic theory, which suggests that resources should flow from capital-abundant to capital-scarce countries where returns on capital are higher [Lucas (1988)].

\footnotetext{
15 The net barter terms of trade are measured by the ratio between the unit value index of exports and that of imports.

16 The growing scale of external liabilities and inability of countries to honor their external commitments is partly at the core of the Highly Indebted Poor Country initiative, which provided debt relief to a large number of low-income countries committed to the PRSP process. For further details see World Bank (1999).

${ }^{17}$ In fact, according to Summers (2006), the buildup of reserves in the developing world and large flow of capital from the most successful emerging markets economies to traditional industrial countries is the most surprising development in international finance over the last decades.

${ }^{18}$ Indeed, this characterization may be one of the most important aspects of the new globalization landscape, especially given that most developing countries acceding to independence primarily earned foreign exchanges from exports of primary commodities and natural resources.
} 
Invariably, these important mutations in the global economy are partly facilitated by the ability of emerging market economies to adopt and apply new technologies, a process which requires significant investments in scientific and technological infrastructures to fully benefit from the diffusion of technology underlying the new globalization landscape. This is all the more important because the diversification of sources of growth in the most successful emerging markets economies was enhanced by lateral shifts of their underlying production functions. And with the rapid reduction in the technological gap, the production function of these economies is converging towards global technology frontiers.

Conversely, the static model of time-invariant sources of growth underpinning production processes in scores of countries in Sub-Saharan Africa widened the region's technology and productivity gap and undermined prospects for economic diversification. The growth volatility and abysmal contribution of Sub-Saharan Africa to global growth during the period of exceptional boom in international trade is partly the consequence of poor scientific and technological infrastructure and rapid depreciation of gross capital formation in a context of declining investment rates in the region [Akyuz and Gore (2001), Bayraktar and Fofack (2007)].

Presumably, there are other related costs associated with the underlying policy of time-invariant drivers of growth adopted by the majority of countries in Sub-Saharan Africa. Key among them is the continued marginalization of the region in the new globalization landscape of deepening integration of world economies. This marginalization is surely another important stylized fact characteristic of the new globalization landscape. The persistence of the debt-poverty trap in a region that continues to be saddled with debt and is slated to miss the first Millennium Development Goals of halving poverty by 2015 is probably another additional consequence [Easterly (2002, 2009), Sun (2004), Berg and Qureshi (2005)]. ${ }^{19}$

However, historical trends suggest that the transition from primary commodities and raw materials exports as drivers of growth to industrial output-based growth requires adoption of new development models, which emphasize value addition and economic diversification. Looking forward, a greater integration of Sub-Saharan African countries into the new globalization landscape may require structural and institutional transformation in support of economic diversification. The next sections explore the determinants of globalization which have contributed to the emergence of the new globalization landscape, and outline their implications for the choice of development models by Sub-Saharan African countries.

\section{Analytical Framework}

Economic theory teaches us that countries involved in international trade are linked through the balance of payments, which summarizes economic and financial transactions between residents and nonresidents in a given cycle. Since globalization is defined as an unprecedented surge in global trade, the emergence of a new globalization landscape should be reflected in the balance

\footnotetext{
19 The accumulation of external liabilities might have been exacerbated by excess capital flight, especially when externally borrowed funds provide the resources and motivations for capital flight—-debt-fueled capital flight hypothesis [Ndikumana and Boyce (2008)]. At the same time, a massive outflow of funds entertained over a long period creates a financing gap often bridged through external financing, a scenario generally known as capital flight-driven external borrowing. In spite of access to debt relief under the Enhanced HIPC Initiative, debt sustainability indicators have been deteriorating rather rapidly in a number of post-Completion Point countries [World Bank (2007)].
} 
of payments stance. Understandably, the new globalization landscape is producing winners and losers, henceforth labeled as 'globalizers' and 'globalizees', respectively. ${ }^{20}$ Reflecting this dichotomy in the balance of payments the losers or 'globalizees' are confronting trade deficits and rising external indebtedness; the winners or 'globalizers' are accumulating balance of payments surplus and excess foreign reserves.

Against this background, we begin this analytical framework with a national account identity. Taking the view of 'globalizers', the current account surplus should be exactly equal to the excess of aggregate national output over aggregate expenditure on goods and services. Alternatively, the current account can also be represented in terms of savings, investments, and government primary balance as follows:

$$
X-M=Y-E=S-I+(T-G)
$$

The variable $(X)$ in equation (1) stands for income receipts from the rest of the world and can be taken to represent exports. The variable $(M)$ stands for payments to the rest of the world for imports of goods and services. On the right hand side, $Y$ stands for national output and $(E)$ is aggregate expenditures (public and private). In order to focus on trade, identity (1) can also be represented in terms of exports performance as follows:

$$
X=Y+M-E
$$

The analysis is primarily concerned with the temporal and spatial dimensions of globalization, which has impacted growth and welfare on the spherical space over the past decades. For instance, technological change in OECD countries is a group specific characteristic that may, nonetheless, affect global export and distribution of growth in the medium to long term. Hence, we use a panel analysis to account for this duality. In addition to spatial and temporal analysis, unbalanced panel models are even more suitable, especially given the existence of missing values. Under this model, equation (2) can now be represented as follows:

$$
X_{i t}=\alpha_{0}+\beta_{i t} Y_{i t}+\beta_{2} w_{i t}+\cdots+\beta_{n} w_{n t}+\varepsilon_{i t}
$$

Where $X_{i t}$ represents exports of country $i$ at time $t$; and the right hand side variables are potential determinants of exports. Export performance very much depends on productivity growth and underlying production function. In order to account for this in modeling specification, assume that the main difference between the 'globalizers' and the 'globalizees' relates to their production function. The accumulation of sustained current account surpluses is greater in countries which have a more diversified production structure, and hence are less exposed to negative terms of trade shocks [Acemoglu and Zilibotti (1997)]. In this regard and with the rapidly changing patterns of growth in emerging economies, let's specify the production function as a variant of the generalized Cobb-Douglas taking the following form:

$$
Y_{t}=A_{t}^{\xi} B_{t}^{\tau} L_{t}^{\alpha} K_{t}^{\beta}, 0<\alpha<1,0<\beta<1, \xi>0, \tau>0
$$

\footnotetext{
20 Taking the views of the critics and institutional approach, the globalizers may also be defined as the set of countries and institutions which are being globalized against their will under the Washington Consensus. For further details, see Woods (2006).
} 
The variable $(Y)$ is the production function and aggregate output is produced from labor $(L)$ and capital $(K)$ under certain technology and institutional setting. This function is twice differentiable with respect to $(L)$ and $(K)$. Its first derivatives are positive, the second derivatives are negative, and the cross-derivative between $(L)$ and $(K)$ is positive. Technology is growth-enhancing, particularly through the productivity channel. Hence output growth is an increasing function of capital and labor. Growth is derived from a transcendental production function, which has $A_{t}^{\xi}$ as the general level of technology and $B_{t}$ is the efficiency vector. The parameters $\alpha, \beta$ and $\tau$ represent the production elasticities of labor, capital and efficiency variable, respectively. The parameter $\xi$ associated with $A_{t}$ is the technology-output elasticity.

Following Papageorgiou and Perez-Sebastian (2002), R\&D provides the global link in the new knowledge economy dominated by exports of manufactured goods. Productivity growth therefore depends on the existing stock of ideas and the number of people devoting their time to research. In practice, inventions made in the rest of the world can be absorbed by local scientists at a cost that is inversely proportional to the country's technological endowment in the absence of institutional barriers to technology diffusion. In this case, the level of technology differs, depending on whether a country is operating in the league of 'globalizers' or 'globalizees'. Taking these assumptions into account, technology evolves according to the following:

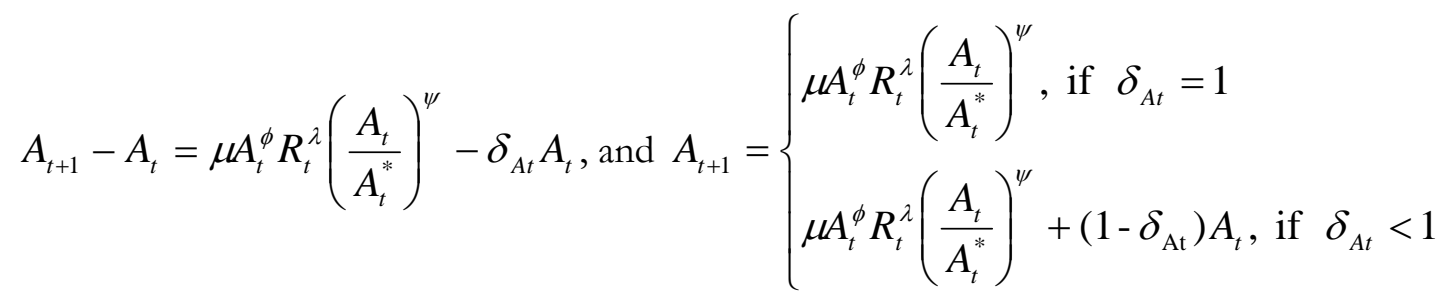

where $\phi<1,0<\lambda \leq 1, \psi>0$, and $A_{t}^{*} \geq A_{t}$ and $0<\left(\frac{A_{t}}{A_{t}^{*}}\right) \leq 1, \quad \forall t$.

The vector $A_{t}^{*}$ is the global technology frontier, uniformly superior to the state of technology in the globalizees' nation $\left(G_{Z E}\right)$ and growing exogenously. If $\left(A_{t}\right)$ is the state of technology in any given country, then $0<\left(\frac{A_{t}}{A_{t}^{*}}\right)<1$, if $A_{t} \in G_{Z E}$. The time-invariance assumption underlying production functions in these countries reflects persistent 'technology lag'. In contrast, the vector $A_{t}$ is converging towards the global technology frontier in the globalizers' nations, that is $0<\left(\frac{A_{t}}{A_{t}^{*}}\right) \rightarrow 1$, if $A_{t} \in G_{Z R} \cdot{ }^{21}$ For all practical purposes, we will assume that the set of

\footnotetext{
${ }^{21}$ Note that $G_{Z E}$ and $G_{Z R}$ are disjoint sets, representing the globalizees and globalizers nations, respectively. Hence, $\left(G_{Z R} \cap G_{Z E}=\varnothing\right)$ and $\left(G_{Z R} \cup G_{Z E}=U\right)$, where $U$ is the global universe of nation states.
} 
globalizers' comprises of traditional industrialized countries and successful emerging market economies; while the globalizees mainly comprises low-income countries.

Moreover consistent with the technology trap hypothesis, the model assumes widening technology gap in low-income countries, hence the technology gap parameter $\psi>0$ [Fofack

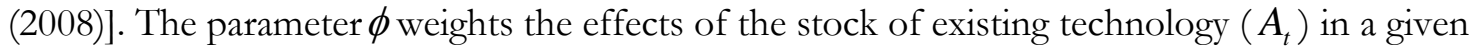
country on $R \& D$ productivity. At the same time, $R \& D$ productivity is proportional to the state of technology and grows accordingly. The rate of depreciation of the capital stock $\left(\delta_{A t} \in(0,1]\right)$ is assumed higher in low-income countries, the result of systemic under-maintenance and declining investment budget $[\mathrm{Bu}(2006)] .22$ Accordingly, if $\delta_{A t}^{*}$ is the depreciation rate in frontier technology nations, then $\delta_{A t} \geq \delta_{A t}^{*}, \forall t$.

To the extent that industrial output expansion and the production of manufactured goods require a minimum level of relevant technology, the model is technology-driven, and $R_{t}$ represents the proportion of researchers in any economy at time $t$. Over time, the stock of researchers depends on the size of the active labor force, investment in higher education and human capital improvement through on-the-job training and the going stock of 'brain drain'. Furthermore, the growth of this stock critically depends on countries' distance from the global technology frontier and the business climate. The higher the initial stock of human capital, the more productive investments in human capital will be. Following Lucas (1988), the rate of change in the population of qualified researchers between periods is represented by:

$$
R_{t+1}=\left(1+\gamma^{\theta}-\omega\right) R_{t}
$$

For $0<\theta<1,0 \leq \omega \leq 1,0<l<1, \gamma>0$ and where $l$ is the proportion of workers investing in human capital improvement. This variable is growing by a factor of $\gamma$ according to an exponential rate $\theta$. The parameter $\omega$ captures the brain drain effect. This parameter $(\omega=0)$ when no qualified researcher leaves the country, an assumption which implies that the country has a conducive environment and is operating on the global technology frontier. Conversely, $(\omega=1)$ if all highly-skilled people automatically migrate to greener pasture. ${ }^{23}$ The actual labor force can be represented in terms of researchers by $L_{t}=R_{t} / p_{t}$, where $p_{t}$ is the proportion of qualified researchers in the active labor force, and $R_{t}$ evolves according to (6).

If $\lambda$ captures the decreasing returns to $\mathrm{R} \& \mathrm{D}$ efforts and $\mu$ is the overall technology parameter, then the country's technology level in the next period can be expressed in terms of a global 'technology lag', the stock of researchers and the level of technology in the previous period. Accordingly, aggregate output growth can be expressed in terms of skilled labor. Furthermore,

${ }^{22} \mathrm{Bu}$ found depreciation rates of capital stocks to be excessively high in developing countries and particularly in Sub-Saharan Africa. For instance, Ghana had a depreciation rate averaging 50 percent for machinery and equipment.

${ }^{23}$ The two-period model can also be extended to inter-generational human capital transfers if the intertemporal human capital spillovers across generations are positively linked to human capital accumulation in the next period. In other word, the higher the inherited stock of human capital the more productive investments in human capital will be. 
$\mathrm{R} \& \mathrm{D}$ productivity is proportional to the state of technology and grows with the extent of integration into the world economy. Assuming that deepening integration into the world economy is the natural path for accessing new technologies for globally competitive economies in a context of technology diffusion. ${ }^{24}$

In addition to the marginalization, the persistent technology gap in low-income countries also depends on a number of factors, including institutional incentives and efficiency considerations. In a number of models, efficiency is captured by openness to trade [Sachs and Warner (1997)]. Others have modeled efficiency using country risks [Knack and Keefer (1995)].25 Here we take a slightly different approach to emphasize the diversification of sources of growth which is essential for integrating the global economy, increasingly driven by manufactured goods. In particular, efficiency variables include the index of economic diversification, reallocation of labor across sectors, a measure of competitiveness and a host of institutional factors, including governance and macroeconomic instability.

The emphasis on economic diversification reflects the nature of the new globalization landscape and the positive association between invariance in sources of growth and the poverty trap [Fofack (2008)]. In fact, Acemoglu and Zilibotti (1997) attribute the proliferation of low return investments and limited growth potential in low-income countries to the deficit of diversification. At the same time, institutional factors, and particularly governance and property rights are critical for sustained investment and long-run economic growth [World Bank (2002b), Rodrik (2008)].

In order to account for these growth-enhancing factors, let $B_{t}$ in (6) be the efficiency vector. Further, let's assume that output growth is inversely related to macroeconomic instability and poor governance. Conversely, suppose that output growth and productivity are proportional to successful economic diversification, as the latter has the potential for enhancing export performance and integration into the global economy. Building on Kneller and Stevens (2002), efficiency factors can be represented by (7):

$$
B_{t}=\exp \left(d_{t}^{\sigma} a_{t}^{v} c_{t}^{\rho}\right) * \exp \left(-u_{t}^{\kappa} g_{t}^{v}\right)
$$

where the variable $d_{t}$ stands for economic diversification, $a_{t}$ represents index of reallocation of labor across sectors, $C_{t}$ measures competitiveness represented by the real effective exchange rate. The variables $u_{t}$ and $g_{t}$ are measure of inflation (macroeconomic instability and volatility) and governance, respectively. The parameters $\sigma, v, \rho, \kappa$ and $v$ exhibit constant elasticity of substitution. ${ }^{26}$ Drawing on equations (4)-(7), and expressing labor as a function of researchers, the aggregate production function takes the following forms:

\footnotetext{
${ }^{24}$ Presumably a diffusion process underpinned by a uniform distribution on the spherical space is the ideal model with global benefits. In practice the technology diffusion process is inherently skewed, with only a very limited number of globally competitive and efficient economies operating on the global technology frontier [Lucas (2007)].

${ }^{25}$ However, openness to international trade measured by the propensity to import and export may not necessarily reflect the extent of technology acquisition and assimilation. The composition of exports matters and the share of high-tech exports may appear as a better indicator of integration into the global economy. 26 This formulation is a slightly modified version of Kneller and Stevens (2002). They account for inefficiency by including an indicator variable $\eta_{i t}$ in their model $\left(0<\eta_{i t}<1\right)$. A country is fully efficient and produces on
} 


$$
Y_{t}=\left\{\begin{array}{l}
{\left[\mu A_{t}^{\phi} R_{t}^{\lambda}\left(\frac{A_{t}}{A_{t}^{*}}\right)^{\psi}\right]^{\xi}\left[\frac{\exp \left(d_{t}^{\sigma} a_{t}^{v} c_{t}^{\rho}\right)}{\exp \left(u_{t}^{\kappa} g_{t}^{v}\right)}\right]^{\tau}\left(\frac{R_{t}}{p_{t}}\right)^{\alpha} K_{t}^{\beta}, \text { if } \delta_{A t}=1} \\
{\left[\mu A_{t}^{\phi} R_{t}^{\lambda}\left(\frac{A_{t}}{A_{t}^{*}}\right)^{\psi}+\left(1-\delta_{\mathrm{At}}\right) A_{t}\right]^{\xi}\left[\left[\frac{\exp \left(d_{t}^{\sigma} a_{t}^{v} c_{t}^{\rho}\right)}{\exp \left(u_{t}^{\kappa} g_{t}^{v}\right)}\right]\right]^{\tau}\left(\frac{R_{t}}{p_{t}}\right)^{\alpha} K_{t}^{\beta}, \text { if } \delta_{A t}<1}
\end{array}\right.
$$

Substituting (8) into equation (2), the determinants of globalization can now be derived following estimation of parameters underlying the production function under different scenarios-advanced economies and low-income countries connected to the global market via exports of natural resources and primary commodities by the latter and imports of manufactured goods from the former. Another key attribute of low-income countries is rapid depreciation of the capital stock and the abysmal quality of scientific and technological infrastructures. In contrast, advanced economies which are operating near or on the global production possibility frontiers are more diversified with a growing scale of manufacturing industries employing an increasingly large share of skilled labor as part of inter-sectoral reallocation.

\section{Empirical Analysis and Policy Implications for Sub-Saharan African Countries}

In its current functional form, the globalization function is highly nonlinear, owing to the structure of the production function. In order to facilitate estimation of parameters, a number of assumptions underlying the theoretical model are relaxed. In particular, a reduced form of the model emphasizes high-tech exports and economic diversification in the determinants of globalization. Diversification is primarily captured by the scope of manufactured goods in countries' output and exports, which are given larger weights in the estimation of the diversification variable. ${ }^{27}$ In the absence of a reliably long and consistent series on reallocation of labor across sectors - a plausible index of sectoral diversification - this variable is not included in the empirical model..$^{28}$

In addition to nonlinearity, this relaxation in the empirical specification is also dictated by constraints in data availability and unbalanced panel design. Unlike advanced economies, the data on $R \& D$ is not always available in most developing countries. This framework combines simulation and instrumented variables from OECD countries to derive proxies for a number of variables underlying production in Sub-Saharan Africa. For instance, the population of

the frontier technology when $\left(\eta_{i t}=1\right)$; otherwise it produces inefficiently with the degree of inefficiency measured by the size of $\eta_{i t}$.

27 The diversification index is a variation of Berthélemy and Soderling (2001) who use the composition of exports to OECD countries as a proxy for economic diversification. Although, this measure does not take into account the diversification of nontradables, it is likely that its reliability will be less affected, especially given the extremely high concentration of active labor force in the agricultural sector.

${ }^{28}$ In practice, the implications of not including this variable in the model may be limited for most countries in Sub-Saharan Africa. In the absence of sectoral diversification, the active labor force continues to be overwhelmingly concentrated in the primary sector. 
researchers is used as a proxy for $\mathrm{R} \& \mathrm{D}$, and its elasticity of economic growth is estimated from the panel of OECD countries. ${ }^{29}$

A random number generator is then used to construct a research vector consistent with the empirical distribution, assuming that SSA countries have the lowest number of resident researchers and scientists—less than 100 per million [Westholm (2004), UNESCO (2005)]. Other variables in the model are consistent and accordingly defined. Capital accumulation is proxied by investments. The quality of governance is captured by the corruption index, which is derived from International Country Risk Guide. Net private capital flows and current account series are from the IMF World Economic Outlook. The number of researchers is from the OECD database. The rest of the data is from the World Bank World Economic Indicators.

In what follows, we use a relaxed form of the model to investigate the determinants of globalization. The reference period covers a nearly 20 year time frame, starting in the mid-1980s and running through the end of 2006. This reference period accounts for most of the current wave of globalization. A two-step approach is used to account for differences between the sample of globalizers and globalizees. While the former-set of globalizers' nations-primarily includes OECD countries (industrialized and emerging market economies), the latter-set of globalizees' nations - has a much narrow geographical coverage, restricted to low-income countries in Sub-Saharan Africa. The sample of globalizers comprises 30 OECD countries. In Sub-Saharan Africa, the analysis is based on a sample of 29 countries. ${ }^{30}$

This sequential approach is also motivated by the difference between these two sets of countries, be it from the standpoint of their production function and contribution to global growth, or from the standpoint of their recent export performance. Recall that the new globalization landscape is driven by exports of high-tech and manufactured goods, which account for an increasingly larger share of global trade [World Bank (2005)]. ${ }^{31}$ And to the extent that increases exports in response to rising global demands under this new landscape is more likely in advanced and more diversified economies, an identification of relevant determinants of globalization in these countries could have significant policy implications for growth and integration into the new globalization landscape for Sub-Saharan African countries.

In order to mitigate variance effects on the stability of estimated parameters and for all practical purposes, variables are expressed in logarithmic terms. Hence, in the first empirical model, the log of the response variable - actual level of exports of goods and services-is expressed in terms of prospective determinants of globalization in the linearized model. These determinants are divided into three sub-groups: technology level variables, efficiency factors and traditional

\footnotetext{
${ }^{29}$ In a virtuous cycle the stock of resident researchers can serve as both R\&D input and output. Positive flows and increase in the stock of researchers add to human capital development; innovations and inventions critically depend on the stock of researchers and R\&D budget.

30 The sub-sample of Sub-Saharan African countries includes: Benin, Botswana, Burkina Faso, Burundi, Cameroon, Cape Verde, Central African Republic, Cote d'Ivoire, Ethiopia, Gabon, Gambia, Ghana, Kenya, Madagascar, Malawi, Mali, Mauritius, Mozambique, Namibia, Niger, Rwanda, Senegal, Sierra Leone, South Africa, Swaziland, Tanzania, Togo, Uganda and Zambia.

${ }^{31}$ Interestingly, the rising scope of manufacturing exports is consistent in advanced and developing countries alike; although the significant increase in this component of global trade is compensated by falling natural agricultural and resources exports in the latter. According to the latest statistics, manufacturing exports rose to account for over 90 percent of low-income countries share of world exports; at the same time their share of primary commodities exports fell dramatically, and now account for less than 10 percent [World Bank (2005)].
} 
primary production factors driving aggregate output growth. More specifically, the reduced form of the empirical model is represented by the following:

$$
X_{i t}=\alpha_{0}+\sum_{j=1}^{q} \beta_{i t}^{j} T_{i t}^{j}+\sum_{k=1}^{n} \delta_{i t}^{k} E_{i t}^{k}+\sum_{l=1}^{m} \varphi_{i t}^{l} P_{i t}^{l}+\varepsilon_{i t}
$$

Where $\vec{T}$ is the vector of technology variables (there are a total number of $q$ such variables); $\vec{E}$ is the vector of efficiency variables (there are a total number of $n$ such variables); the vector $\vec{P}$ accounts for traditional primary production factors (the model includes up to $m$ such variables); and $\varepsilon_{i t}$ is the error term for country $i$ at time $t$.

In addition to fixed capital stock and labor, other variables affecting output growth include imports of goods and services, including intermediate goods, total consumption (private and public). Fixed capital stock is estimated by assuming a depreciation rate of $5 \%$ in advanced economies and a higher rate of $(10 \%)$ for Sub-Saharan African countries. ${ }^{32}$ Variables accounting for technology level include high-tech exports, the total number of researchers and manufacturing exports. Efficiency variables include the real effective exchange rate (a rise is a depreciation), inflation, which measures macroeconomic instability and corruption index which measures the countries' stance on governance. The corruption index is inversely proportional to countries' stance on corruption - least corrupt nations are assigned the maximum value. This index has the minimum value of 0 and maximum value of 6 .

Empirical results suggest that high-tech exports, manufactured exports and the population of resident researchers are significant determinants of globalization in the new globalization landscape across OECD countries (see table 1 in Annex). The estimated coefficients associated with these variables all have positive sign, suggesting that increases in the high-tech components of aggregate output and manufacturing exports are positively associated with rise in global trade in the globalizers' nations. And to the extent that these countries account for a sizable share of global trade-more than 66 percent of world total, investments in R\&D, which is critical for innovations, total factor productivity and manufacturing output growth, might have played a critical role in the new globalization landscape [Rebelo (1998), Okubo et al. (2006)].

On average in the sample, global trade increased by nearly .14 percent for every 1 percent increase in exports of manufactured goods in OECD countries, ceteris paribus. Contrasting this contribution with that of other significant determinants, it increases by .06 percent and .03 percent for every 1 percent increase in the population of researchers and total amount of hightech exports ceteris paribus, respectively. However, there may be inter-action effect at play, whereby the accumulation of knowledge and technical know-how enhances productivity growth in high-tech industries and production of manufactured goods [Mansfield (1980)]. In spite of difference in the scale of these estimated parameters, the probability values associated with each are extremely low, suggesting that these determinants are significant at the 1 percent level.

Other significant determinants of globalization include capital, labor, imports and total consumption. Presumably, the significance of consumption reflects rising global demands, which

32 The presumed higher depreciation rate of capital stock in Sub-Saharan Africa is warranted. Bu (2006) found that the stock of fixed capital tends to depreciate at a much higher rate in Sub-Saharan African countries, as compared to normal rates usually assumed in industrialized countries. 
has been sustained throughout the new globalization landscape and up to the global financial crisis [IMF (2007), Adams (2008)]. Similarly, sustained increases in total investments and capital accumulation are partly a response for rising global demands, which should follow through the output growth channel, especially if larger weights are assigned to the production of high-tech and manufacturing goods. On average, global trade increases by .033 percent for every 1 percent increase in the stock of capital net of depreciation, ceteris paribus. The proportional change in global exports associated with total consumption is of similar magnitude.

However, the pertinence of efficiency variables is not as straightforward. Although indicators of good governance and real effective exchange rate are positively related to trade-a real exchange rate depreciation is associated with increases in exports - these variables are not significant, even at the 5 percent level. On the other hand the macroeconomic instability variable, which is significant at the 1 percent level, has a positive sign. However, the coefficient associated with this variable is fairly small, and probably reflects the fact that the decades of sustained output growth and exceptional boom in global trade were also accompanied by price stability [IMF (2006)]. ${ }^{33}$ However, there is a growing concern that rising fiscal deficits and expansionary monetary policies implemented in response to the global financial crisis may fuel inflationary pressures, especially in countries with greater resource intensity [IMF (2009)].

In spite of the relatively low level of significance of these efficiency variables and the relaxation of some of the key hypothesis underlying the theoretical model, the globalizers' actual distribution of exports of goods and services is well captured by predicted values derived from the empirical model. Figure 3 below compares actual (solid thick line) and predicted (solid thin line) distribution of exports of goods and services for these countries. Except at the tail end of the distributions, the absolute deviation between actual and predicted values is almost equal to zero, and the deviation towards the end of the distribution is relatively small.

Turning to the set of globalizees, a variation of the empirical model is applied to data in SubSaharan African countries. Panel estimation results are provided in Table 2 in the Annex. Among the technology level variables, the number of researchers and manufacturing exports are significant determinants of globalization in the region. The resulting $p$-values are close to zero for these variables suggesting that they are both significant at the 1 percent level. This result is consistent with existing empirical studies and analysis of OECD countries' data. In fact, according to a recent study, globalization whether defined in terms of technology diffusion or foreign direct investments, has disproportionately benefited countries with better scientific and technological infrastructures [IMF (2007)].

Moreover, the potential contribution of these variables to total exports for countries in the region is higher in comparisons to that of OECD countries. In particular, exports of goods and services increased by 1.7 percent for every 1 percent increase in the total number of researchers, ceteris paribus. The much higher marginal contribution of technology factors to globalization in these countries probably reflects the initial conditions characterized by poor scientific and technological infrastructures. It also highlights the higher role that science and technology could play in furthering the integration of Africa into the new globalization landscape, increasingly driven by knowledge [Rebelo (1998), Andreosso-O’Callaghan (2002)].

\footnotetext{
${ }^{33}$ Interestingly, globalization might have played a positive role in the exceptionally low rates of inflation in the new globalization landscape. In particular, the relative stability in the flows of private capital throughout the era was a positive factor; at the same time, the low cost of manufactured goods prevented international transmission of inflationary pressures.
} 
Figure 3: Predicted versus actual exports in OECD countries (in billions of US\$)

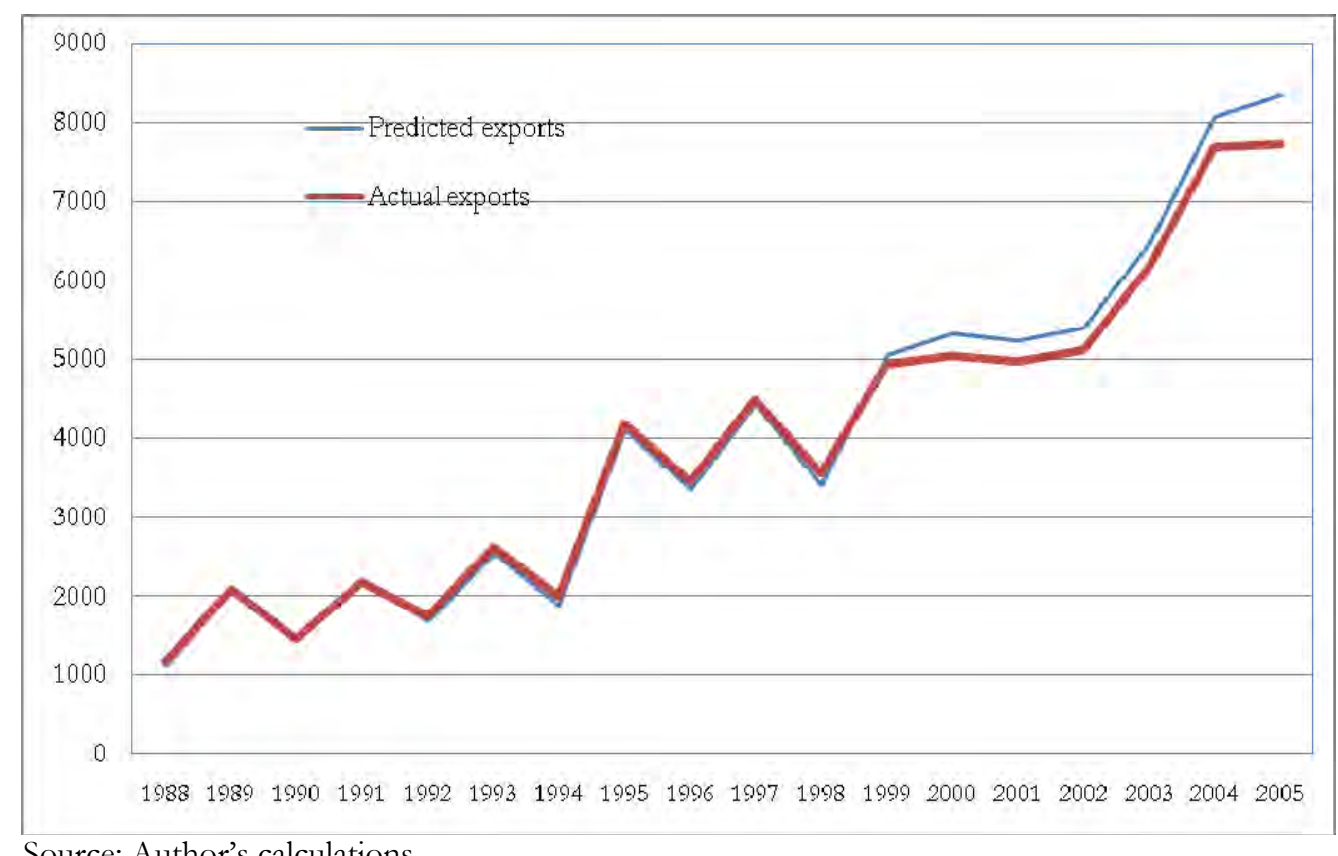

Source: Author's calculations.

Among the efficiency variables, macroeconomic instability (proxied by inflation) and real effective exchange rate (measure of competitiveness) are both significant at the 10 percent level. The coefficient associated with inflation is negative. This suggests that macroeconomic instability may have adversely affected growth and export performance of Sub-Saharan Africa in the new globalization landscape - a result that is consistent with the outcome in the literature and probably reflects a much higher volatility in the region and hence the prohibitively high costs of reversibility of investments. ${ }^{34}$ In fact, contrary to industrialized economies which enjoyed low inflation and macroeconomic stability during most of the globalization era, Sub-Saharan African countries went through decades of structural adjustments programs to address recurrent macroeconomic instability, particularly internal and external deficits and inflationary pressures. ${ }^{35}$

Conversely, the real effective exchange rate (REER) has a positive sign (a rise is a depreciation), suggesting that the degree of competitiveness, and specifically exports potential of Sub-Saharan African economies may improve with a real depreciation of domestic currencies vis-à-vis currencies of their main trading partners. In fact over the years and in line with economic theory, exchange rate adjustments and devaluation have been at the core of adjustment programs implemented by development institutions to reduce external disequilibria and promote economic growth in low-income countries [Montiel (2005), Rodrik (2008)].

\footnotetext{
${ }^{34}$ In fact uncertainty and volatility play a key role in the decision of firm to invest, as it has the potential for raising transaction and adjustment costs. The high adjustment and irreversibility costs of investments in an environment of high macroeconomic uncertainty are often used to justify the higher aversion to risks in lowincome countries. For further details, see Dixit and Pindyck (1994).

35 In fact, in the most extreme cases, numerous countries went through a period of hyper inflation and exchange controls which resulted in the coexistence of official and parallel exchange rates.
} 
However, while these programs had an impact on the current account in the short run, they did not result in increased technological endowment and structural transformations needed for longrun growth and integration into the world economy [Akyuz and Gore (2001)]. As a result most countries in the region remain highly undiversified and expose to negative terms of trade shocks.

Among the traditional primary production factors driving output growth and exports in the region, the significant determinants of globalization include imports of goods and services and fixed capital stock, in that order. These variables are positively related to globalization, with relatively large coefficients. In particular, the elasticity associated with imports is larger than unity, suggesting that exports of goods and services increase by over 1 percent for every 1 percent increases in imports for the sub-region, ceteris paribus.

Similarly, exports of goods and services increase by .29 percent for every 1 percent increases in fixed capital stock, ceteris paribus. Conversely, exports are inversely related to total consumption, and would decrease by .44 percent for every 1 percent increase in total consumption. The much higher marginal reduction of exports following the hypothetical increase in domestic consumption probably illustrates a continued and excessively low level of economic diversification of Sub-Saharan African countries in the absence of manufacturing industries which accounts for a sizable share of the global trade [Goldstein et al. (2006)].

The empirical model is once again used to compare actual and predicted values of exports of goods and services for Sub-Saharan African countries. Figure 4 compares absolute deviations of predicted values (solid thin line) from actual (solid thick line) levels of exports of goods and services. Except for the range covering the late 1990s, the two distributions essentially overlap, further suggesting that the empirical model is effective at modeling the distribution of exports of goods and services of countries in Sub-Saharan Africa.

Figure 4: Predicted versus actual exports from Sub-Saharan Africa (in billions of US\$)

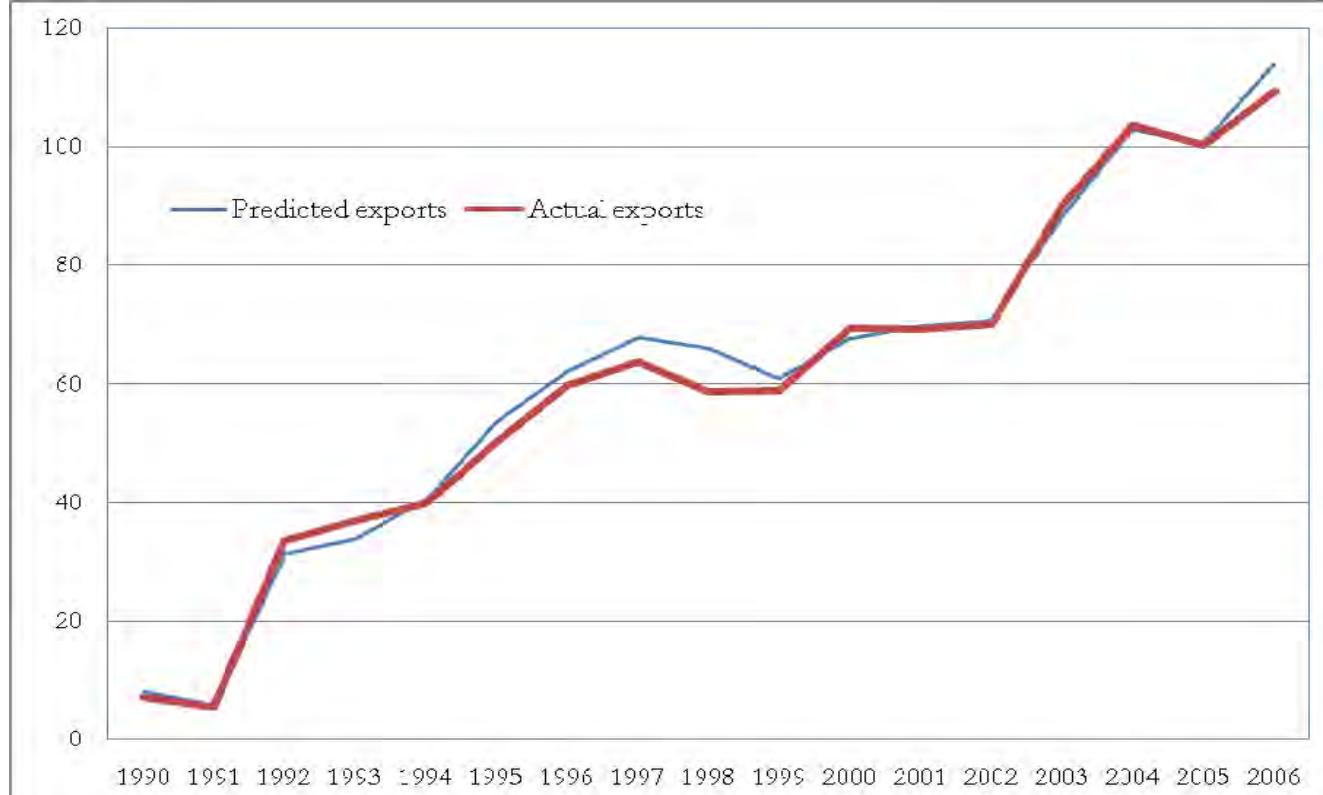

Source: Author's calculations. 
The study also conducts a set of policy experiments to assess the expected impact of some of the key determinants of globalization for output growth and exports in Sub-Saharan Africa. In particular, the empirical model takes the hypothetical assumption that countries in Sub-Saharan Africa are raising their stock of resident researchers and high-tech exports to OECD levels. Although, such assumptions are highly implausible in the short run, especially given the inherent costs in a resource constraint environment, these policy experiments are primarily carried out to motivate the choice of alternative policies promoting economic diversification and structural transformation in the design of national development strategies. ${ }^{36}$ In this regard, the ultimate choice of any given policy experiment could also be informed by costs and benefits analysis in an inter-temporal setting.

The policy experiments emphasize capital accumulation and technological changes, especially given the increasingly greater role played by these factors in the new globalization landscape. Thus, positive shocks are applied to these variables in turn, though a concurrent increase in capital stock and human capital development may, in effect, be a more plausible development model. For instance, a sustained capital accumulation may provide the framework for human capital development in a learning-by-doing model [Jovanovic and Nyarko (1996)]. In this case, the stock of resident researchers may serve as conduit for raising the aggregate flow of researchers, and thus emerge as a key component of R\&D output.

R\&D output can also be measured in terms of increased production of high-tech and manufactured goods. In order to assess this aspect of knowledge-based production, a positive shock is applied to the initial stock of researchers. This shock produces the largest hypothetical increases in Sub-Saharan Africa's exports of goods and services. More specifically, raising the region's stock of researchers to OECD levels results in over tenfold increase in exports of goods and services, ceteris paribus. Figure 5 contrasts the predicted level of exports following the shock (solid and thin line) with actual level of exports (solid and thick line).

Although, less pronounced, a similar widening gap is observed between actual (solid and thick line) and predicted (solid and thin line) values of exports when the positive shock is applied to the high-tech component of aggregate output. A contrast between the two distributions is likewise illustrated by Figure 6 . This hypothetical increase suggests that a structural transformation of African economies resulting in the growth of manufactured goods with hightech components could significantly raise the region's contribution to global trade and hence, strengthen its position in the new globalization landscape.

The last two policy experiments concern shocks on fixed capital stock and governance, which have been identified as major constraints to growth in Sub-Saharan Africa over the last decades [Akyuz and Gore (2001), Fofack and Ndikumana (2009)]. Not surprisingly, raising the governance bar of countries in the Sub-Saharan Africa region to OECD levels results in a dramatic increase in the region's overall exports of goods and services. In particular, exports levels increase by nearly 35 percent under this hypothetical scenario, ceteris paribus (see Figure 1

36 However, these policy experiments are carried out under the ceteris paribus assumption and partial equilibrium model. In practice, a sustained increase in the population of resident researchers should have wideranging implications for growth and welfare, especially in economies with strong forward and backward linkages. In this regard, a more comprehensive model, which provides a framework for integrated analysis, possibly within a general equilibrium framework may be more suitable for assessing the potential impact of these policy experiments [Agénor et al. (2003)]. Nonetheless, we believe that the policy experiments could shed some light on the design of national development strategies. 
in Annex). This increase is illustrated in the consistent gap between actual (solid and thick line) and predicted levels of exports (solid and thin line).

Figure 5: Predicted versus actual exports from Sub-Saharan Africa under the hypothesized assumption of OECD researchers and estimated coefficients (in billions of US\$)

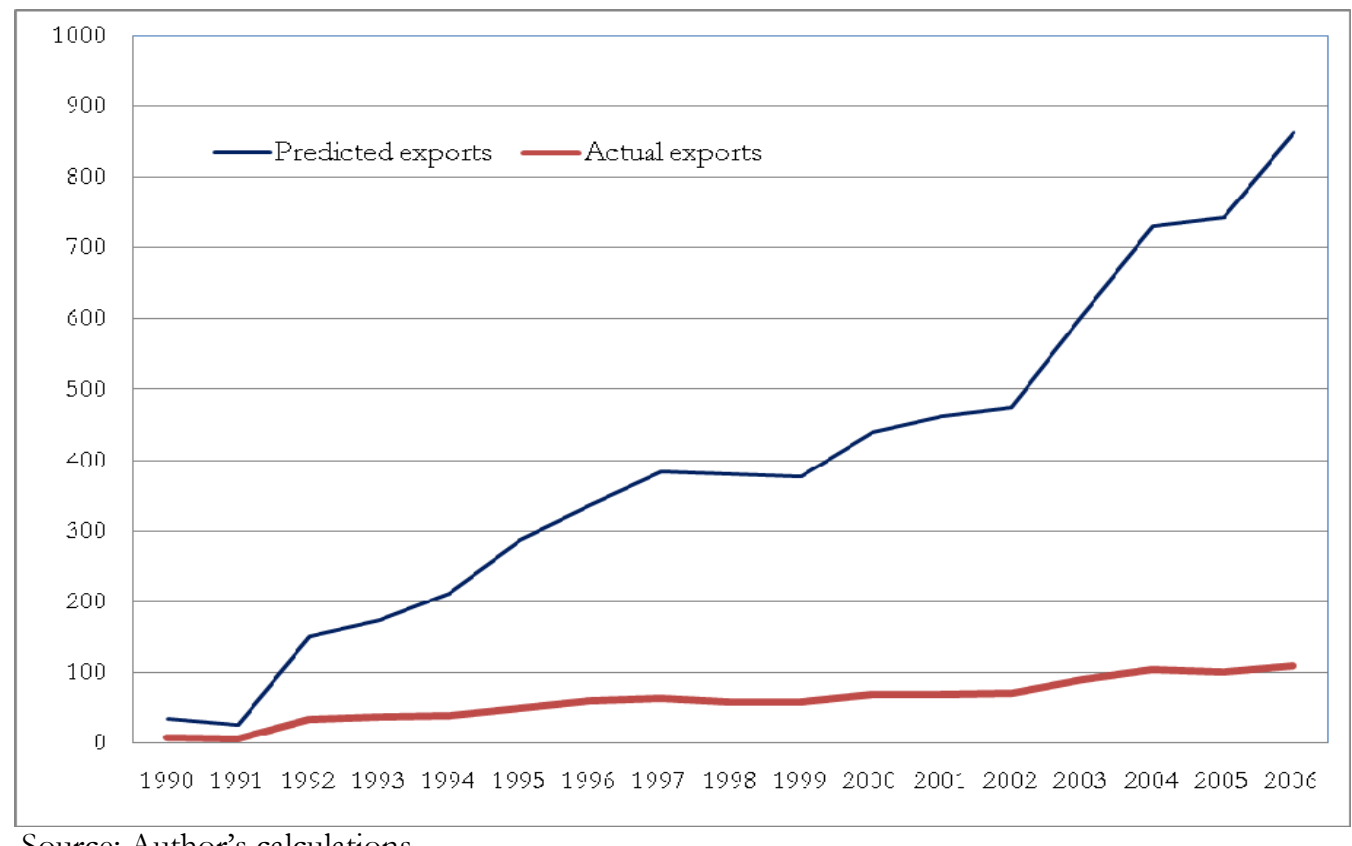

Source: Author's calculations.

Figure 6: Predicted versus actual exports from Sub-Saharan Africa under the hypothesized assumption of OECD high-tech export goods and estimated coefficients (in billions of US\$)

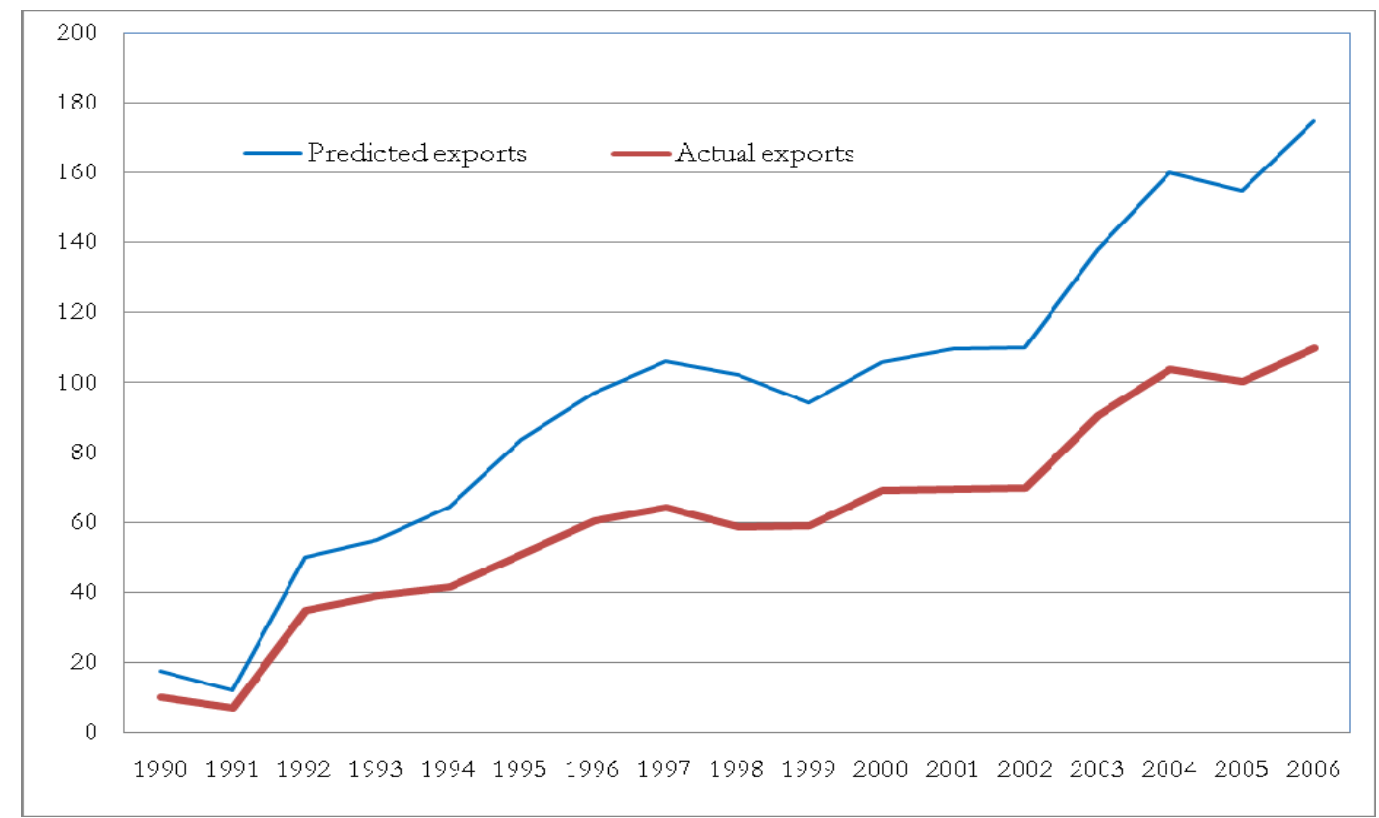

Source: Author's calculations. 
Similarly, raising the Sub-Saharan Africa region's fixed capital stock to OECD levels results in a dramatic increase in the region's share of global trade. This hypothetical gain in the new globalization landscape is illustrated by Figure 2 in the Annex. Again, this last Figure contrasts actual (solid and thick line) with predicted levels of exports (solid and thin line). Under this last hypothetical scenario, the potential gains are even more significant, with the estimated levels of Sub-Saharan African exports growing by more than threefold, ceteris paribus.

\section{Concluding Remarks}

Over the last three decades and up to the global economic and financial crisis, the process of globalization played a key role in the extraordinary and sustained rate of growth recorded in the world, and particularly in emerging market economies. Over time, sustained aggregate output growth, which was driven by rising global demands for manufactured goods, further deepened the integration of world economies. Departing from previous episodes, this last wave of deepening integration of world economies was more inclusive, and resulted in the emergence of a new globalization landscape where emerging market economies are playing an increasingly greater role.

However, in spite of the deepened integration of world economies under this new globalization landscape, the distribution of global trade has not been uniform on the spherical space. A deepened integration of emerging market economies, which saw their share of global trade increase markedly and consistently throughout the span of this new landscape, is in sharp contrast with the increasing marginalization of Sub-Saharan Africa. In fact, the contribution of Sub-Saharan African countries to global trade and exports declined consistently under this new globalization landscape, producing a modern lopsided version of globalization, characterized by growing income and welfare gaps between emerging market economies and Sub-Saharan African

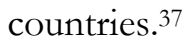

Indeed the deepening integration of world economies under the new globalization landscape enhanced income convergence between industrialized and emerging markets economies. This convergence is a reflection of important structural transformations undertaken by emerging market economies. These transformations are particularly illustrated by increased technological endowments in support of production of high-tech and manufactured goods in these economies. There are other factors which contributed to the globalization of these economies, however. This study uses pseudo panel models to investigate these determinants. Empirical results single out technology level variables, and particularly the stock of resident researchers, the component of high-tech and manufactured goods in aggregate output and exports as the significant determinants of global trade.

The study also undertakes a number of policy experiments, counterfactually assessing the potential growth and globalization effects of bridging technology gaps between Sub-Saharan African countries and industrialized economies. These policy experiments highlight the potential growth and welfare benefits of increased technological endowment for Sub-Saharan African countries. In particular, hypothetically raising the Sub-Saharan African stock of resident

\footnotetext{
${ }^{37}$ Previous episodes of globalization were equally lopsided, with the first world producing manufactured goods in the post-industrial revolution and the second world primarily engaged in the production of land-intensive primary commodities. However, the lopsided structure placed all developing countries under the same category. For further details, see World Bank (2002).
} 
researchers or high-tech component of aggregate output to OECD levels dramatically increases the contribution of the region to global trade. Similar benefits are highlighted when Sub-Saharan Africa's fixed capital stock and governance are hypothetically raised to OECD levels.

Interestingly, these variables, and especially the technology-related ones, are significant when the model is applied to OECD countries as well as to countries in Sub-Saharan Africa. The spatial invariance of technology-related variables, irrespective of countries' stance on the development ladder reflects the declining share of primary commodities and natural resources exports in global trade and the increasing share of high-tech and manufactured goods. This evolving trend in the new globalization landscape has significant implications for growth in Sub-Saharan Africa. In particular, national development strategies should emphasize investments which lead to structural transformation, shifting the production function away from primary commodities and natural resources exports to increased production of high-tech and manufactured goods.

Nevertheless, the success on this development path requires increased scientific and technological endowment, and improved governance and business climate. Over the years, globalization has disproportionately benefited countries which have institutional frameworks for advancing research and knowledge acquisition in support of innovation, total factor productivity growth and industrial output expansion. Consistent with historical trends, this paper has highlighted the potential effects of improved technological endowments for Africa's export performance and integration into the new globalization landscape, analytically and through counterfactual policy experiments.

However, the illustrative policy experiments amount to partial equilibrium analysis conducted under the ceteris paribus assumption. In practice, the scale of high-tech components of aggregate output and exports surely depends on the stock of resident researchers, and hence academic institutions and business climate. Similarly, improved governance should attract foreign direct investments and raise the domestic capital stock in a context of globalization of capital flows. Future research could investigate the potential joint effect of increased capital stock and technological endowment for countries in Sub-Saharan Africa in a generalized equilibrium framework, which takes into account forward and backward linkages and interaction effects. 


\section{References:}

Acemoglu D. and F. Zilibotti (1997). "Was Prometheus Unbound by Chance? Risk Diversification and Growth". Journal of Political Economy, 105, 709-751.

Adams F. Gerard (2008), “Globalization,” World Economics, Vol. 9 (2), pp. 153-74.

Agénor Pierre-Richard (2002). "Does globalization Hurt the Poor?". World Bank Policy Research Working Paper No. 2922, The World Bank Group, Washington DC.

Agénor Pierre-Richard, Alejandro Izquierdo and Hippolyte Fofack (2003). “The integrated macroeconomic model for poverty analysis: a quantitative macroeconomic framework for the analysis of poverty reduction strategies," World Bank Policy Research Working Paper; No. 3092.

Agosin, Manuel R. (2005). "Export Diversification and Growth in Emerging Economies." Mimeo, Department of Economics, Universidad de Chile.

Akyuz, Yilmaz and Charles Gore (2001). "African Economic development in a Comparative Perspective," Cambridge Journal of Economics, Vol. 25, 265-288.

Nadreosso-O'Callaghan Bernadette (2002). "Human Capital Accumulation and economc Growth in Asia," Working Paper No. 30.

Artadi V. Elsa and Xavier Sala-i-Martin (2003). “The Economic Tragedy of the 20 ${ }^{\text {th }}$ Century: Growth in Africa”, National Bureau of Economic Research Working Paper No. 9865.

Bayraktar, Nihal and Hippolyte Fofack. (2007). "Specification of Investment Functions in SubSaharan Africa," World Bank Policy Research Working Paper No. 4171, the World Bank Group.

Berg, Andy and Zia Qureshi. (2005). “The MDG’s: Building a Momentum,” Finance and Development, the International Monetary Fund. Vol. 42. Number 3.

Ben-David, Dan. (1998). "Free trade, growth, and convergence." Journal of Economic Growth. Vol. 3. pages. 143-70 (June).

Berthélemy Jean-Claude (2001). "The Role of Capital Accumulation, Adjustment and Structural Change for Economic Take-Off: Empirical evidence from African Growth Episodes”. World Development, Vol. 29, No. 2, pp. 323-343.

Bu Yisheng (2006). "Fixed Capital Stock Depreciation in Developing Countries: Some Evidence from Firm Level Data", Journal of Development Studies, Vol. 42, No. 5, 881-901.

Coulibaly Brahima and Jonathan Millar (2008). "The Asian Financial Crisis, Uphill Flow of Capital and Global Imbalances: Evidence from A Micro Study". Board of Governors of the Federal Reserve System, Washington DC.

Dixit A. and Pindyck R. (1994). Investment under Uncertainty. Princeton University Press.

Easterly William and Ross Levine (1997). "Africa's Growth Tragedy: Policies and Ethnic Divisions”, Quarterly Journal of Economics.

Easterly William (2002). "How did Heavily Indebted Poor Countries Become Heavily Indebted? Reviewing Two Decades of Debt Relief”, World Development Vol. 30, No. 10, pp. 1677-1696.

Easterly William (2009). “Can the West Save Africa?”, Journal of Economic Literature, 47:2, 373447.

Elbadawi Ibrahim, Benno Ndulu, Njuguna Ndung'u (1997). "Debt Overhang and Economic Growth in Sub-Saharan Africa", in Iqbal and Kanbur eds. External Finance for Low-Income Countries, International Monetary Fund, Washington DC. 
Fofack Hippolyte (2008). “Technology-Trap and Poverty Trap in Sub-Saharan Africa”, World Bank Policy Research Working Paper No. 4582, The World Bank Group.

Fofack Hippolyte and Leonce Ndikumana (2009). "Potential Gains from Capital Flight Repatriation for Sub-Saharan African Countries", Forthcoming World Bank Policy Research Working Paper.

Friedman Thomas (2005). The World is Flat: A Brief History of the Twenty-First Century. Farrar, Strauss and Giroux, USA.

Gerchenkron Alexander (1962). Economic Backwardness in Historical Perspective. Cambridge, MA:

Belknap Press.

Goldstein Andrea, Nicolas Pinaud, Helmut Reisen and Xiaobao Chen (2006). "The Rise of China and India: What's in it for Africa?" OECD Development Centre Studies. The Organization for Economic Cooperation and Development, Paris, France.

World Economic Outlook

International Monetary Fund (2006). World Economic Outlook: Globalization and Inflation. (April)

International Monetary Fund (2007). "World Economic Outlook: Globalization and Inequality", The International Monetary Fund, Washington DC.

International Monetary Fund (2009). "World Economic Outlook: Financial Stress, Downturns, and Recoveries", The International Monetary Fund, Washington DC.

Jovanovic Boyan and Yaw Nyarko (1996). "Learning-by-Doing and the Choice of Technology", Econometrica, 64, 1299-1310.

Knack S. and P. Keefer (1995). "Institutions and Economic Performance: Cross-Country Test using Alternative Institutional Measures", Economics and Politics, 7, 207-227.

Kneller R. and P. Stevens (2002). "The Role of Efficiency as an Explanation of International Income Differences”, National Institute Discussion Paper No. 206.

Leamer Edward (2007). “A Flat, A Level Playing Field, a Small World After All, or None of the Above?” Journal of Economic Literature, Vol. 45, No. 1.

Lucas Robert E. (1988). “On the Mechanics of Economic Development", Journal of Monetary Economics, Vol. 22 (1) 3-42.

Lucas Robert E. (2007). “Trade and the Diffusion of the Industrial Revolution”, NBER Working Paper No. 13286.

Maddison Angus (1995). "Monitoring the World Economy, 1820-1992". Paris: Organization for Economic Cooperation and Development.

Maddison Angus (2001). “The World Economy: A Millennial Perspective”. Paris: Organization for Economic Cooperation and Development.

Mansfield, Edwin (1980). "Basic research and Productivity Increase in Manufacturing," American Economic Review, Vol. 70 (5), pp. 863-73.

Mathews John and Mei-Chih Hu (2007). "Universities and Public Research Institutions as Drivers of Economic Development in Asia", in S. Yusuf and K. Nabeshima, eds, "How Universities Promote Economic Growth", The World Bank.

Montiel, Peter J. (2005). "Public Debt Management and Macroeconomic Stability: An Overview," the World Bank Research Observer, Vol. 20(2), pp. 259-81.

Mundell Robert (1997). “The International Monetary System of the $21^{\text {st }}$ Century: Could Gold Make a Comeback?”, Columbia University, New York. 
Ndikumana Leonce and James Boyce (2008). "New Estimates of Capital Flight from Sub-Saharan African Countries: Linkages with External Borrowing and Policy Options". Political Economy Research Institute Working Paper No. 166. University of Massachusetts Amherst.

Ndulu Benno (2006). "Challenges of Africa's Growth: Opportunities, Constraints and Strategic Directions." The World Bank, Washington DC.

Okubo Sumiye, Carol A. Robbins, Carol E. Moylan, Brian K. Sliker, Laura Schultz and Lisa S. Mataloni (2006). "R\&D Satellite Account: Preliminary Estimates", Bureau of Economic Analysis Working Paper No. BEA 06-44, Bureau of Economic Analysis, US Department of Commerce.

Papageorgiou Chris and Fidel Perez-Sebastian (2002). "Human Capital and Convergence in NonScale R\&D Growth Model”, Unpublished Manuscript.

Rebelo Sergio (1998). “The Role of Knowledge and Capital in Economic Growth”, World Institute for Development Economics Research Working Paper No. 149. The United Nations University, WIDER.

Reinhart Carmen and Kenneth Rogoff (2009). "The Aftermath of Financial Crises". National Bureau of Economic Research, NBER Working Paper No. 14656.

Rodrik Dani (2008). "Second Best Institutions", The American Economic Review, Papers and Proceedings 2008, 98:2, 100-1004.

Sachs Jeffrey and A. M. Warner (1997). "Sources of Growth in African Economies." Journal of African Economies, Vol. 6, No. 3.

Stiglitz Joseph (2003). “The Roaring Nineties: Globalization and Its Discontents”. W. W. Norton \& Company, New York.

Stiglitz Joseph (2006). "Making Globalization Work”. W. W. Norton \& Company, New York.

Summers, Lawrence H. (2006). "Reflection on Global Account Imbalances and Emerging Markets

Reserve Accumulation.” L.K. Jha Memorial Lecture, Reserve Bank of India, March 24, 2006.

Sun Yan (2004). "External Debt Sustainability in HIPC Completion Point Countries", IMF Working Paper, WP/04/160, The International Monetary Fund, Washington DC.

UNESCO (2005). "State of Science and Technology Training Institutions in Africa," United Nations Educational, Scientific and Cultural Organizations, regional Bureau for Science in Africa, Nairobi, Kenya.

Westholm Gunnar, Bertrand Tchatchoua and Peter Tindemans (2004). "Measuring Progress

Towards Knowledge Societies", A World Science, Vol. 2, No. 1.

Woods Ngaire (2006). "The Globalizers: The IMF, The World Bank and Their Borrowers". Cornell University Press, Cornell University.

World Bank (1999). Building Poverty Reduction Strategies in Developing Countries, September.

World Bank (2002a). "Globalization, Growth and Poverty: Building an Inclusive World Economy”. World Bank Policy Research Report. The World Bank Group, Washington DC.

World Bank (2002b). “World Development Report 2002: Building Institutions for Markets", International Bank for Reconstruction and Development, The World Bank.

World Bank (2005). Economic Growth in the 1990s: Learning from a Decade of Reform. The World Bank, Washington D.C.

World Bank (2006). "Global Development Finance: The Development Potential of Surging Capital Flows", The World Bank Group, Washington DC. 
World Bank (2007). "Global Development Finance: The Globalization of Corporate Finance in Developing Countries", The World Bank Group, Washington DC.

Yusuf, Shadid and Kaoru Nabashima (2007). "How Universities Promote Economic Growth," Directions in Development, the World Bank. 


\section{Annexes}

Table 1: Panel regression results from OECD countries

\begin{tabular}{|c|c|c|c|c|}
\hline \multicolumn{5}{|c|}{$\begin{array}{l}\text { Dependent Variable: LOG(EXP?) } \\
\text { Method: Pooled Least Squares } \\
\text { Date: 06/25/09 Time: 09:50 } \\
\text { Sample (adjusted): } 19882006 \\
\text { Included observations: } 19 \text { after adjustments } \\
\text { Cross-sections included: } 30 \\
\text { Total pool (unbalanced) observations: } 379\end{array}$} \\
\hline Variable & Coefficient & Std. Error & t-Statistic & Prob. \\
\hline LOG(HIGH?) & 0.029948 & 0.010294 & 2.909316 & 0.0038 \\
\hline LOG(RESEARCHER?) & 0.056294 & 0.015334 & 3.671237 & 0.0003 \\
\hline LOG(MANUEXP?) & 0.137737 & 0.020309 & 6.782004 & 0.0000 \\
\hline LOG(REER?) & 0.058251 & 0.037853 & 1.538872 & 0.1247 \\
\hline INF? & 0.005641 & 0.001084 & 5.203411 & 0.0000 \\
\hline CORRUP? & 0.007258 & 0.005957 & 1.218576 & 0.2238 \\
\hline LOG(LAB?) & -0.117248 & 0.016400 & -7.149096 & 0.0000 \\
\hline LOG(CAP?) & 0.032819 & 0.016585 & 1.978819 & 0.0486 \\
\hline LOG(IMP?) & 0.791765 & 0.029301 & 27.02196 & 0.0000 \\
\hline LOG(CONS?) & 0.066531 & 0.025064 & 2.654411 & 0.0083 \\
\hline R-squared & 0.992655 & \multicolumn{2}{|c|}{ Mean dependent var } & 25.33171 \\
\hline Adjusted R-squared & 0.992476 & \multicolumn{2}{|c|}{ S.D. dependent var } & 1.326457 \\
\hline S.E. of regression & 0.115058 & \multicolumn{2}{|c|}{ Akaike info criterion } & -1.460729 \\
\hline Sum squared resid & 4.884954 & \multicolumn{2}{|c|}{ Schwarz criterion } & -1.356836 \\
\hline Log likelihood & 286.8081 & \multicolumn{2}{|c|}{ Hannan-Quinn criter. } & -1.419500 \\
\hline Durbin-Watson stat & 0.199305 & & & \\
\hline
\end{tabular}


Table 2: Panel regression results from Sub-Saharan African countries

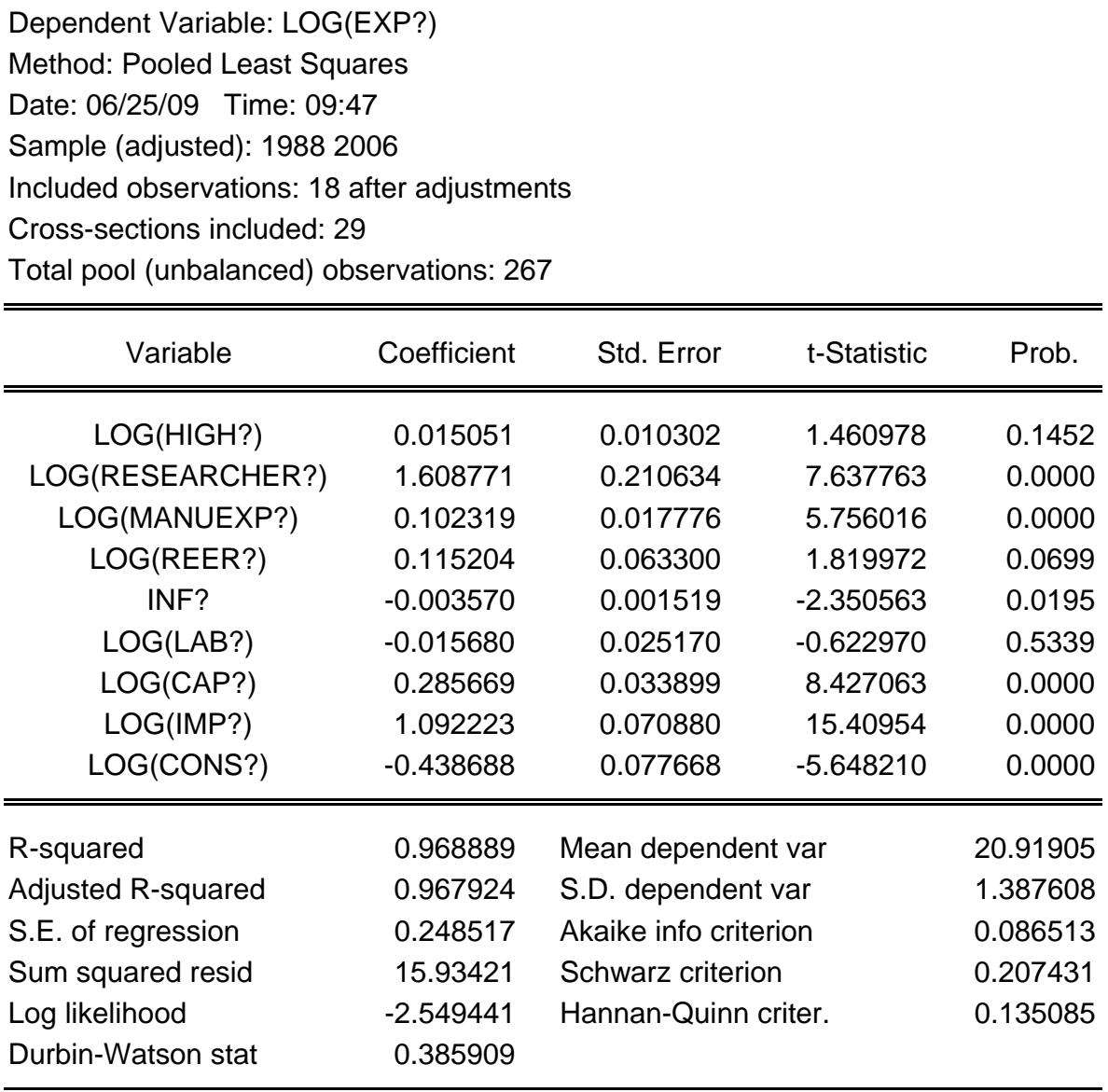


Figure 1: Predicted versus actual exports from Sub-Saharan Africa under the hypothesized assumption of improved governance to OECD levels and higher estimated coefficients (in billions of US\$)

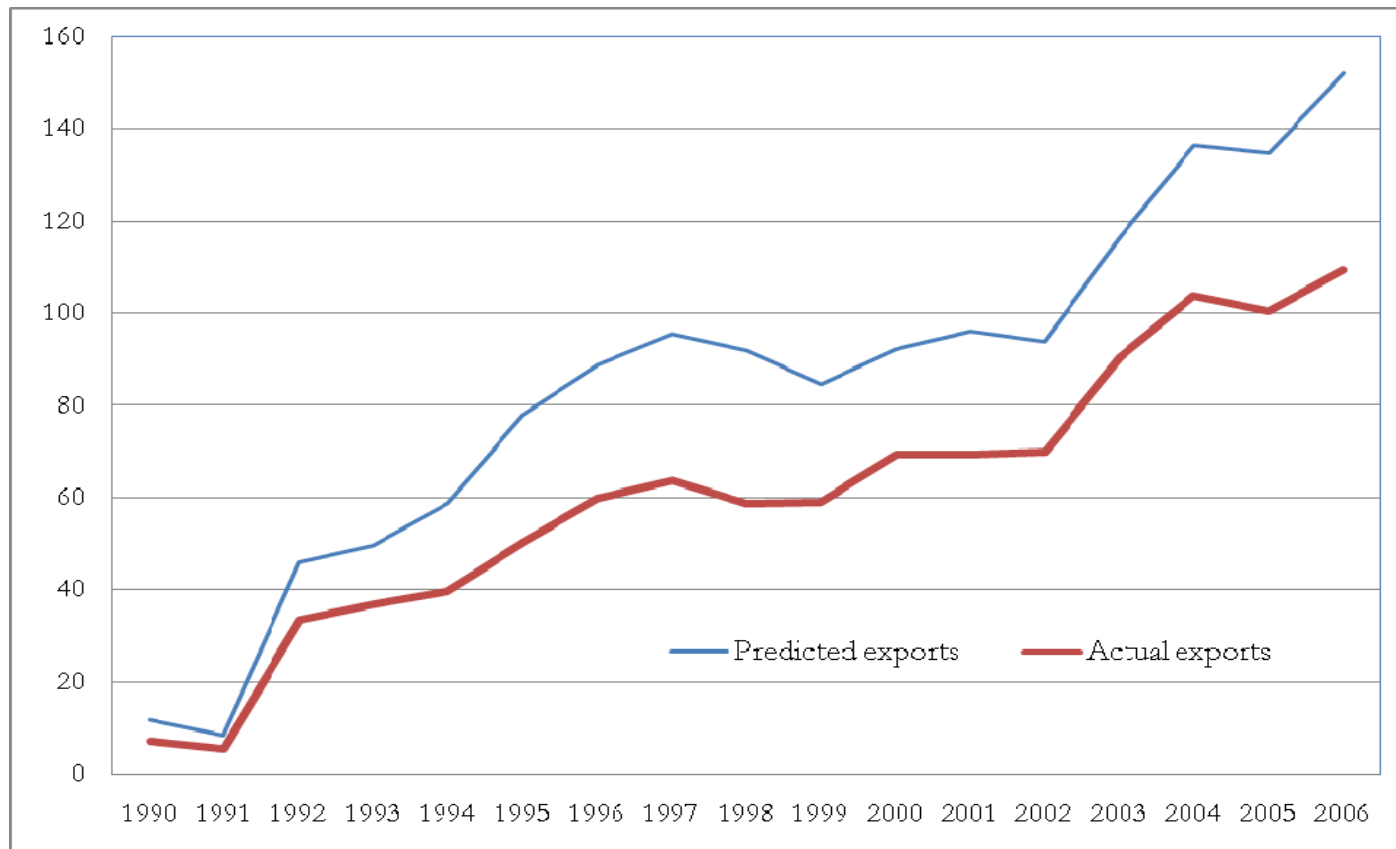

Source: Author's calculations.

Figure 2: Predicted versus actual exports from Sub-Saharan Africa under the hypothesized assumption of increased Sub-Saharan Africa's capital stock to OECD levels (in billions of US\$)

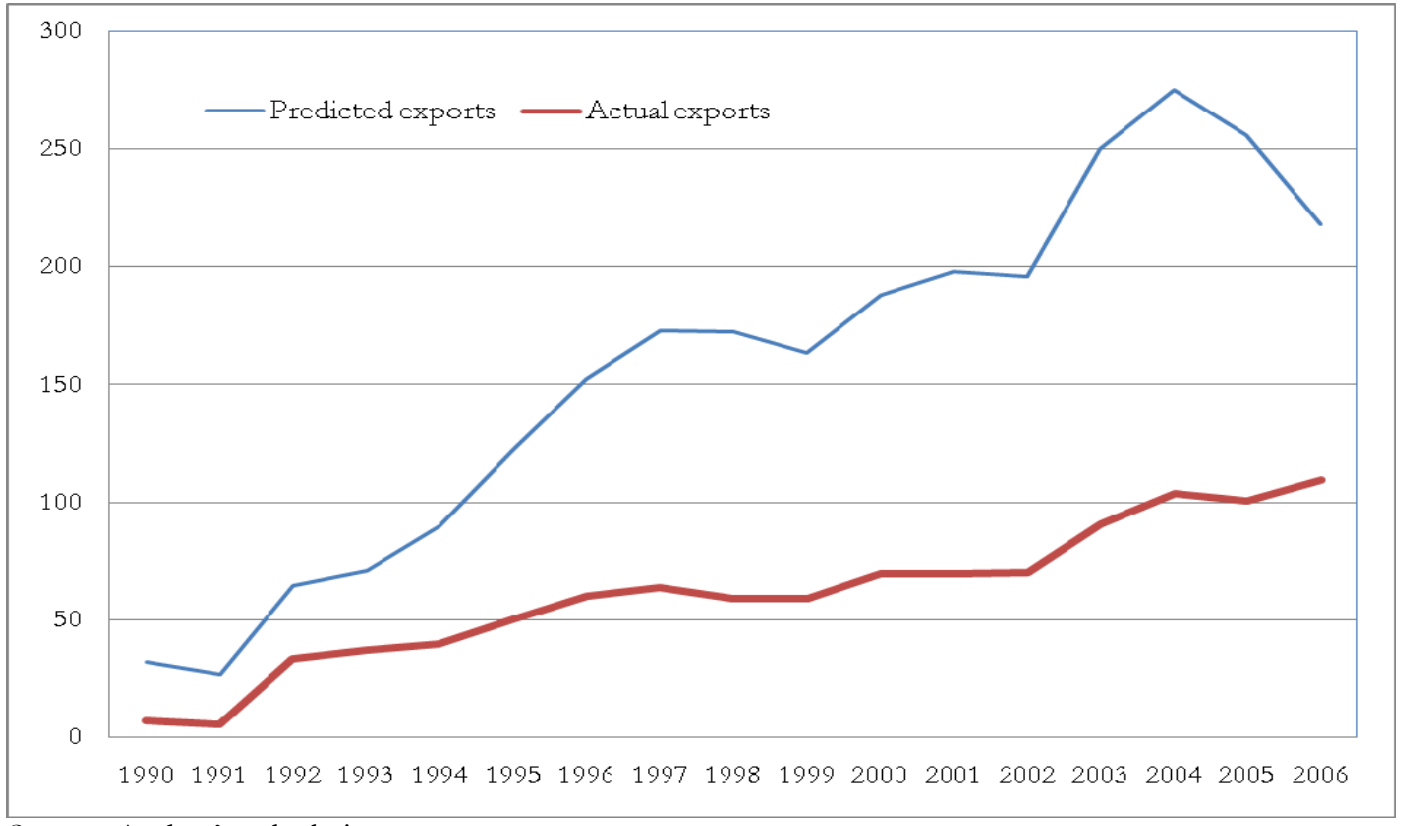

Source: Author's calculations. 
